\title{
Overview and Comparative Assessment of Single-Phase Power Converter Topologies of Inductive Wireless Charging Systems
}

\author{
Phuoc Sang Huynh *(D), Deepak Ronanki ${ }^{\circledR}$, Deepa Vincent ${ }^{\circledR}$ and Sheldon S. Williamson * \\ Smart Transportation Electrification and Energy Research (STEER) Group, Department of Electrical, Faculty of \\ Engineering and Applied Science, Computer and Software Engineering, University of Ontario Institute of \\ Technology (Ontario Tech University), Oshawa, ON L1G 0C5, Canada; dronanki@ieee.org (D.R.); \\ deepa.vincent@ontariotechu.net (D.V.) \\ * Correspondence: phuoc.huynh@ontariotechu.net (P.S.H.); sheldon.williamson@uoit.ca (S.S.W.)
}

Received: 22 March 2020; Accepted: 22 April 2020; Published: 1 May 2020

\begin{abstract}
The acquisition of inductive power transfer (IPT) technology in commercial electric vehicles (EVs) alleviates the inherent burdens of high cost, limited driving range, and long charging time. In EV wireless charging systems using IPT, power electronic converters play a vital role to reduce the size and cost, as well as to maximize the efficiency of the overall system. Over the past years, significant research studies have been conducted by researchers to improve the performance of power conversion systems including the power converter topologies and control schemes. This paper aims to provide an overview of the existing state-of-the-art of power converter topologies for IPT systems in EV charging applications. In this paper, the widely adopted power conversion topologies for IPT systems are selected and their performance is compared in terms of input power factor, input current distortion, current stress, voltage stress, power losses on the converter, and cost. The single-stage matrix converter based IPT systems advantageously adopt the sinusoidal ripple current (SRC) charging technique to remove the intermediate DC-link capacitors, which improves system efficiency, power density and reduces cost. Finally, technical considerations and future opportunities of power converters in EV wireless charging applications are discussed.
\end{abstract}

Keywords: AC-AC converters; battery chargers; electric vehicles; power conversion harmonics; wireless power transmission

\section{Introduction}

The electrification of transportation has been considered as a promising solution to tackle greenhouse gas emissions and fossil fuel depletion. To boost the market share of electric vehicles (EVs), their inherent issues such as limited driving range, long charging time, and costly and cumbersome energy storage systems should be resolved. Wireless charging technology can mitigate the aforementioned issues [1-10]. Wireless power transfer (WPT) enabling transferring energy from a source to a load without electrical contact has been extensively studied and successfully demonstrated using various techniques, namely, acoustic power transfer (APT) [11,12], radio frequency power transfer (RFPT) [13,14], optical power transfer (OPT) [15,16], capacitive power transfer (CPT) [17], and inductive power transfer (IPT) [18]. However, it is well demonstrated from the literature that the IPT technology is the most suitable for EV charging applications where the power requirement is form few to several $\mathrm{kW}$, and the air gap varies from a few centimeters to a few meters [5]. Particularly, researchers and engineers have fitted the outcomes of the IPT to EV battery charging applications with various commercial products and standards [19]. The IPT chargers offer with several benefits such as 
safety, convenience, flexibility, weather immunity, and the possibility of range extension and battery volume reduction $[1,8,10,20,21]$. The wireless chargers can be deployed in residential garages, and office/service/shopping center parking lots for static wireless charging [22], or they can be placed at bus stops, taxi ranks, and traffic lights to implement quasi-dynamic wireless charging [23]. Moreover, dynamic wireless charging systems can be installed on the roads to constantly charge the EVs, in turn, to extend the driving range and reduce the battery volume of the vehicles [24-26].

Essentially, an IPT charging system comprises an inductive coupling coil pair, compensation networks, primary converters to generate high-frequency inputs, and a secondary rectifier to convert AC to DC current to charge the battery. In the IPT charging systems, power electronic converters make a significant contribution to the size and cost, and efficiency of the overall system. Typically, dual-stage conversion (AC-DC-AC) systems have been employed to excite the IPT systems, as shown in Figure 1a. The dual-stage converter topologies are intensively studied and widely used in industry [27-29]. The main advantage of these topologies is that each conversion stage can be separately designed and controlled to optimize specific performance indices. However, the presence of multiple conversion stages and a bulk DC-link capacitor increases the cost, size, and weight of the system. In recent years, the use of matrix converters (MCs) for feeding the IPT systems has drawn increasing attention [30-38]. MCs enable direct conversion of low-frequency AC inputs (50-60 Hz) to high-frequency outputs (up to $85 \mathrm{kHz}$ ) without any intermediate conversion stage; therefore, they enhance the system performance in terms of power density, reliability, and cost [32,39]. The single-phase matrix converter-based IPT systems remove the DC-link energy storage elements in the primary side to absorb double line frequency ripple, thus it appears on the battery side. Sinusoidal ripple current (SRC) charging technique reported in [40-45] allows batteries to be charged by double line frequency (100 or $120 \mathrm{~Hz})$ current with minor side effects on their performance. Therefore, matrix converter-based IPT systems can use the sinusoidal charging technique advantageously and remove the intermediate DC-link capacitor. The single-stage EV IPT charging system using MCs is illustrated in Figure $1 \mathrm{~b}$.

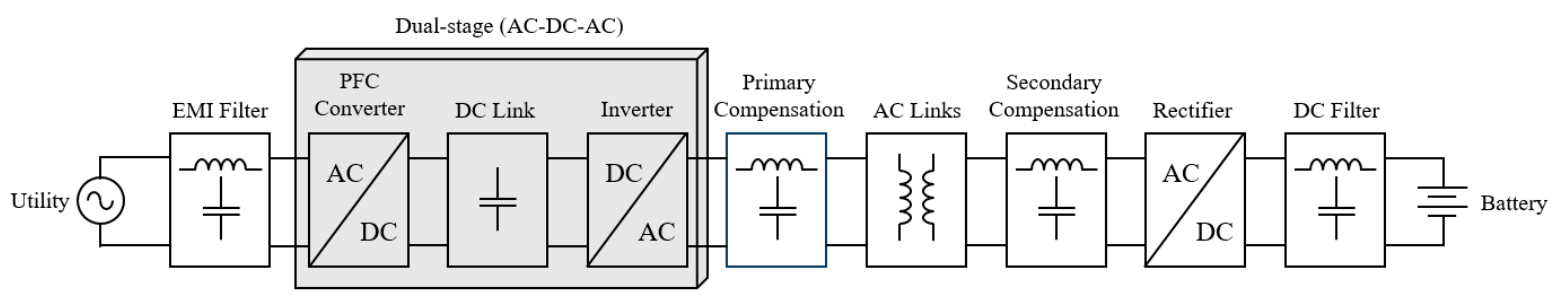

(a)

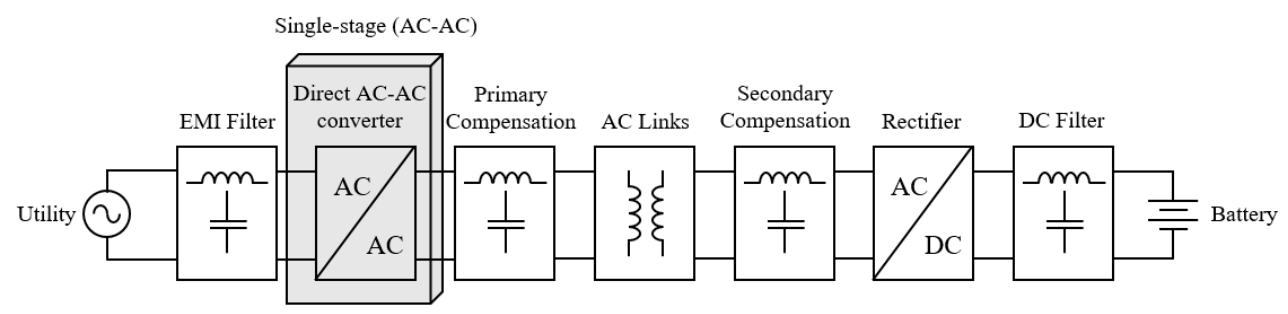

(b)

Figure 1. Configuration of electric vehicle (EV) inductive power transfer (IPT) systems with (a) dual-stage power conversion and (b) single-stage power conversion. PFC, power factor correction; EMI, electromagnetic interference.

This paper aims to provide an extensive overview of single-phase power conversion topologies employed in static wireless charging. Then, a comprehensive performance comparison between the conventional dual-stage (power factor correction (PFC) and full-bridge voltage source inverter (VSI)) 
and single-stage topologies including the buck-derived full-bridge (FB)MC and boost-derived FBMC in the IPT EV charging application is presented. The comparison involves the input power factor, input current distortion, power losses, switching stress, and normalized cost, while taking into account the requirements of Standard J2954 [19] established by the Society of Automotive Engineers (SAE). The Standard SAE J2954 defines acceptable criteria for interoperability, electromagnetic compatibility, electromagnetic field (EMF), minimum performance, safety, and testing for wireless charging of light-duty electric vehicles. Table 1 shows the power classes, operating frequency, and efficiency performance targets of the WPT systems defined in the SAE J2954. As can been seen, four wireless power transfer (WPT) classes are defined based on the maximum input volt-amp (VA) drawn from the grid by the primary side or ground assembly (GA) electronics. The input real power depends on the input power factor, while the output power depends on the efficiency of the system. The SAE J2954 specifies that WPT systems should be operated at a single nominal frequency of $85 \mathrm{kHz}$. However, for WPT systems using frequency control to compensate operating variations, their operating frequency must be tuned in the band of 81.38 to $90.00 \mathrm{kHz}$. Finally, the improvement opportunities for each of the IPT charging topologies are discussed in this paper.

Table 1. Wireless power transfer (WPT) power classification for light-duty electric vehicles—SAE J2954.

\begin{tabular}{ccccc}
\hline WPT Levels & $\mathbf{1}$ & $\mathbf{2}$ & $\mathbf{3}$ & $\mathbf{4}$ \\
\hline Maximum AC input power (kVA) & 3.7 & 7.7 & 11 & 22 \\
Minimum target efficiency at nominal alignment (\%) & $>85$ & $>85$ & $>85$ & To be defined (TBD) \\
Minimum target efficiency at offset position (\%) & $>80$ & $>80$ & $>80$ & TBD \\
Operating frequency (kHz) & & & $81.38-90$ (typical 85) \\
\hline
\end{tabular}

\section{Power Converter Topologies for Inductive Wireless Charging}

In this section, an overview of front-end converter topologies for WPT applications is provided. They can be classified into two groups, namely dual-stage and single-stage based on the power conversion stages. The classification of single-phase converter topologies for IPT systems is shown in Figure 2.

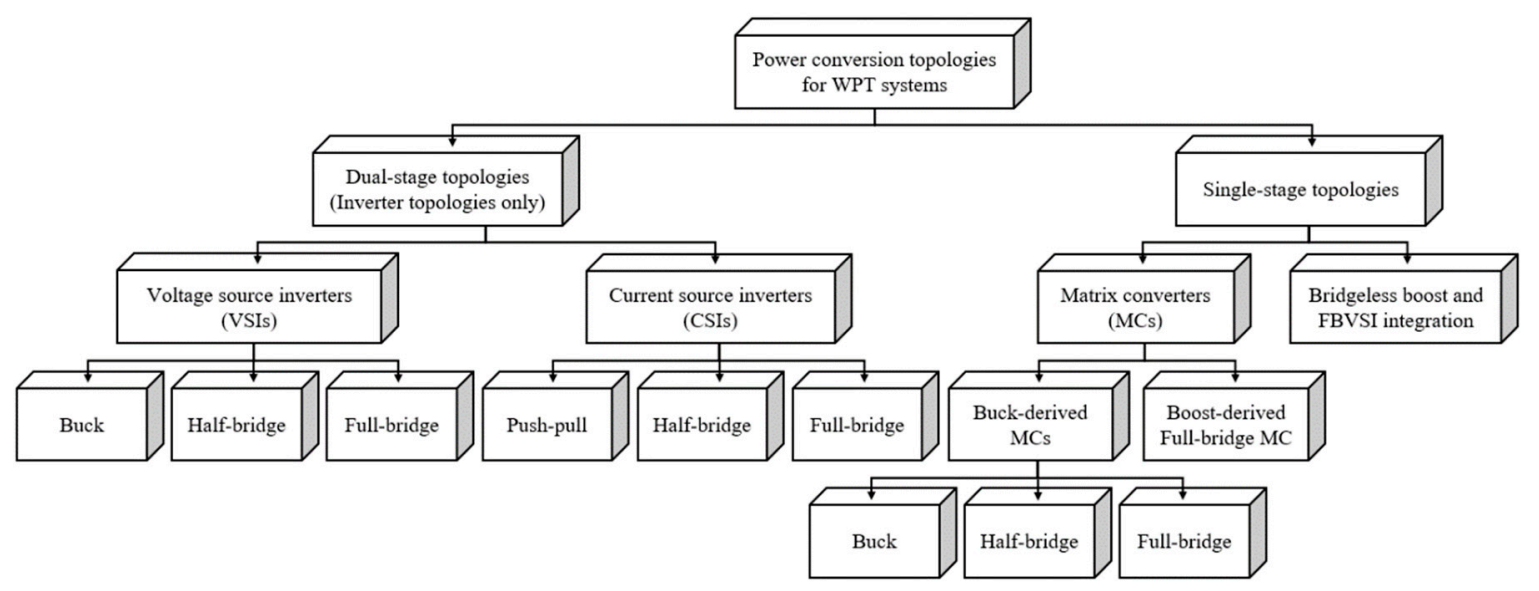

Figure 2. Classification of front-end converter topologies for IPT applications. FB, full-bridge; WPT, wireless power transfer.

\subsection{Dual-Stage Power Conversion}

A front-end AC-DC converter is used to convert the supply AC voltage to an intermediate DC-link voltage and to shape the input current for both PFC and harmonic reduction. A comprehensive review for the PFC rectifiers is presented in [46,47]. For the inversion stage, a current-source inverter (CSI) or a VSI can be employed. 
Two CSI topologies commonly used in IPT systems are push-pull, half-bridge [48-53], and full-bridge $[54,55]$. Figure $3 a-c$ shows the configuration of CSIs. The requirement of blocking diodes and bulky inductors that increases the size and cost of the whole IPT system is one of the major drawbacks of the CSIs. A single parallel compensating capacitor in the primary circuit is normally used with CSIs; however, the inverter switches suffer high voltage stress in high-power applications $[48,50,52,54]$. In order to overcome this drawback, a parallel-series CC compensation circuit is introduced in $[53,55]$. The CSIs combined with the parallel-series CC compensation circuit mitigates current and voltage stress on inverter switches and harmonic contents in primary coil current.

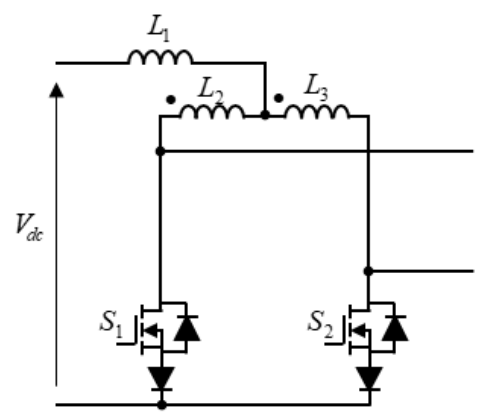

(a)

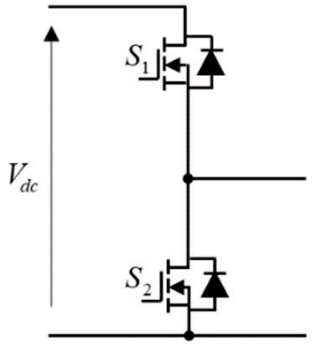

(d)

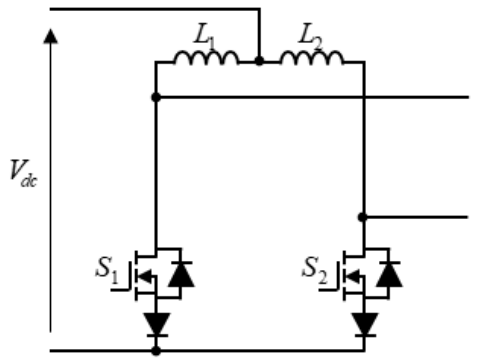

(b)

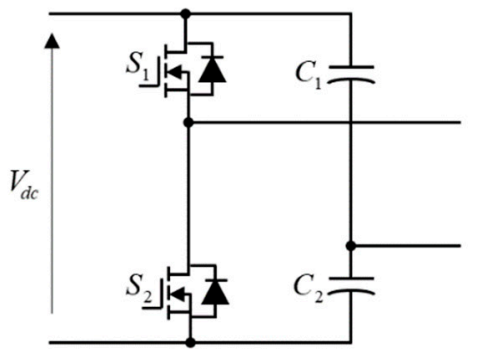

(e)

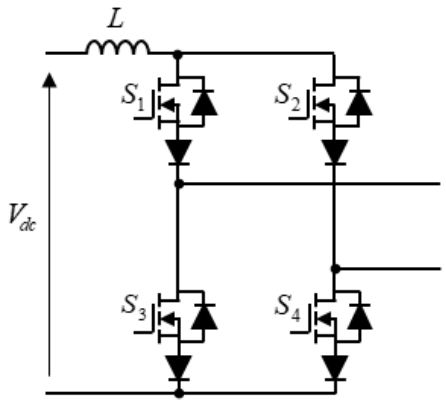

(c)

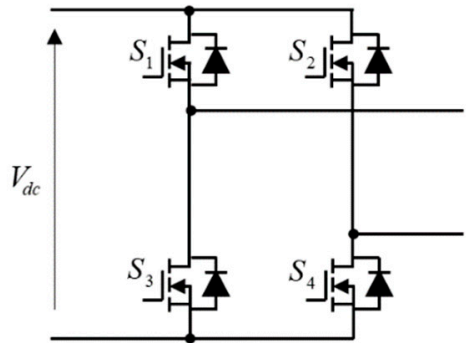

(f)

Figure 3. Inverter topologies: (a) push-pull, (b) half-bridge CSI, (c) full-bridge CSI, (d) buck, (e) half-bridge VSI, and (f) full-bridge VSI.

For VSI topologies, buck, half-bridge, and full-bridge topologies shown in Figure $3 \mathrm{~d}-\mathrm{f}$ can be used in the IPT systems, and they are compatible with single capacitor series, $L C L$, and LCCL compensation networks $[1,21,56-66]$. The series compensation is simple and cost-effective. However, under light load conditions or in the absence of the receiver, the system experiences severe instability $[67,68]$. $L C L$ or LCCL tanks overcome these issues and have a high tolerance to coil misalignments [68]. However, a significant amount of lower-order harmonics in the output current of the VSIs connected with $L C L$ and LCCL compensation circuits deviates zero-phase-angle operation of the inverters, increasing their switching losses [69]. Moreover, the inductors in $L C L$ and $L C C L$ compensation circuits must be designed precisely as the effective power transfer capability is highly sensitive to the inductance value $[57,61]$. Figure 4 shows the compatibility of the inverter types and primary compensation circuits of the IPT systems. Table 2 shows the comparison of the inverter topologies regarding the component requirement. It can be seen that the CSIs require more components than the VSIs. 


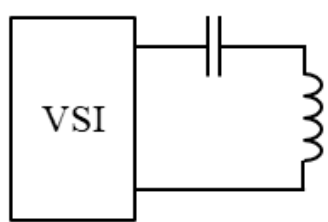

(a)

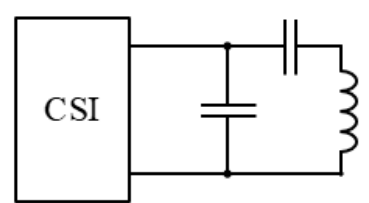

(d)

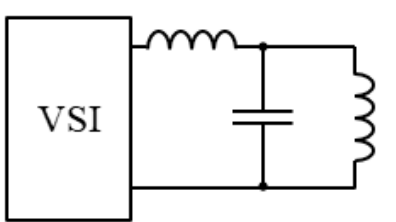

(b)

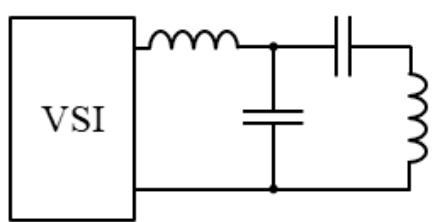

(c)

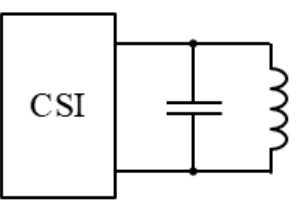

(e)

Figure 4. Compatibility between inverter types and primary compensation circuits in IPT systems. (a) Series $C$, (b) $L C L,(\mathbf{c}) L C C L,(\mathbf{d})$ parallel $C$, and (e) parallel-series $C C$.

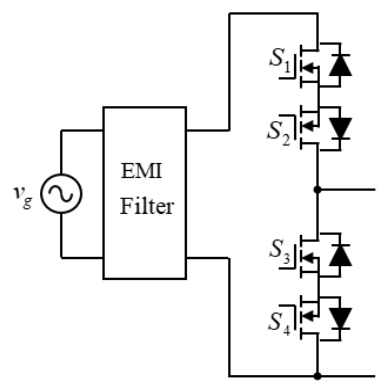

(a)

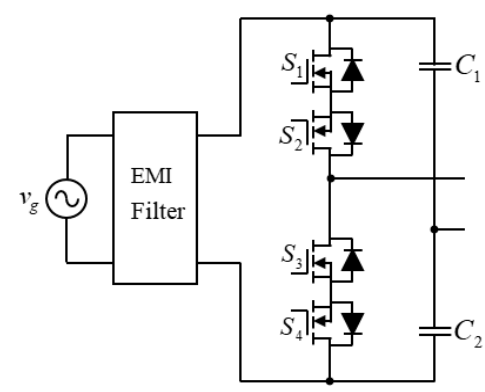

(b)

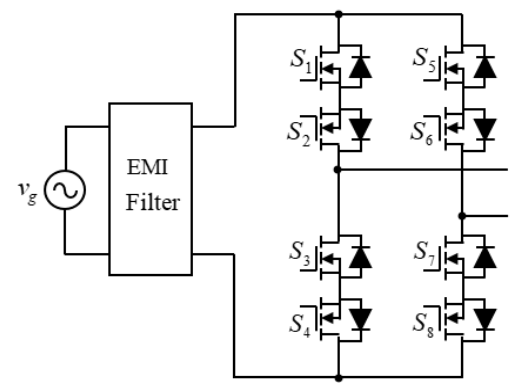

(c)

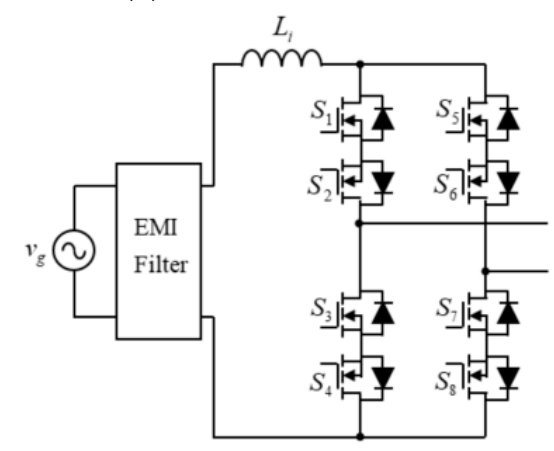

(d)

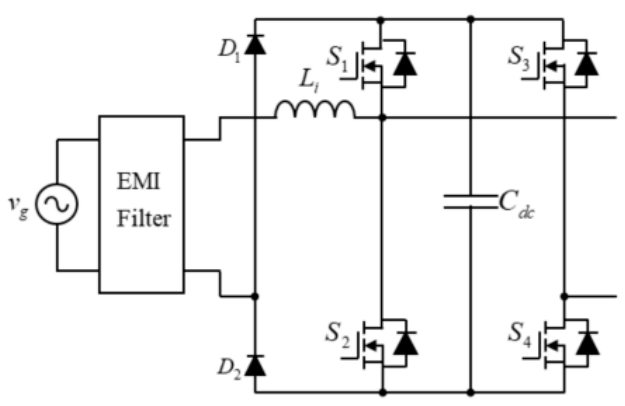

(e)

Figure 5. Single-stage conversion topologies: (a) buck matrix converter, (b) half-bridge matrix converter, (c) full-bridge matrix converter, (d) boost-derived matrix converter, and (e) bridgeless boost converter. 
Table 2. Power conversion topologies and control schemes of the inductive power transfer (IPT) systems

\begin{tabular}{|c|c|c|c|c|c|}
\hline \multirow{2}{*}{\multicolumn{2}{|c|}{ Power Conversion Topologies }} & \multirow{3}{*}{$\begin{array}{l}\text { Figure } \\
\text { Figure 3a }\end{array}$} & \multicolumn{2}{|c|}{ Component Requirement } & \multirow{2}{*}{ Control Schemes } \\
\hline & & & Switches & Passive Components & \\
\hline \multirow{4}{*}{$\begin{array}{l}\text { Dual-stage (excluding } \\
\text { front-end PFC stage) }\end{array}$} & $\begin{array}{l}\text { Current-source push-pull } \\
\text { Current-source half-bridge }\end{array}$ & & $\begin{array}{l}2 \text { reverse blocking } \\
2 \text { reverse blocking }\end{array}$ & $\begin{array}{l}1 \text { inductor, } \\
1 \text { phase-splitting } \\
\text { transformer } \\
2 \text { inductors }\end{array}$ & $\begin{array}{l}\text { - Variable switching frequency } \\
\text { DC-link voltage control } \\
\text { - Secondary-side control } \\
\text { Dual-side control }\end{array}$ \\
\hline & Current-source full-bridge & Figure $3 c$ & 4 reverse blocking & 1 inductor & $\begin{array}{ll} & \text { Variable switching frequency } \\
\text { - } & \text { DC-link voltage control } \\
\text { - Pulse width modulation (phase-shift control) } \\
\text { - } & \text { Decondary-side control } \\
\end{array}$ \\
\hline & $\begin{array}{l}\text { Voltage-source buck } \\
\text { Voltage-source half-bridge }\end{array}$ & Figure $3 d$ & 2 reverse conducting & 2 capacitors & 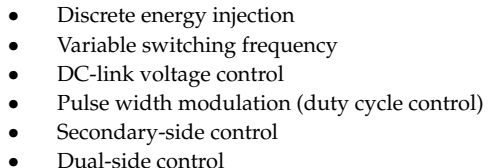 \\
\hline & Voltage-source full-bridge & Figure $3 \mathrm{f}$ & 4 reverse conducting & None & $\begin{array}{ll} & \text { Discrete energy injection } \\
\text { - } & \text { Variable switching frequency } \\
\text { - } & \text { PC-link voltage control } \\
\text { - } & \text { Secondary-side control } \\
\text { Dual-side control }\end{array}$ \\
\hline \multirow{5}{*}{ Single-stage } & Buck MC & Figure $5 a$ & 2 bidirectional & None & \multirow[t]{2}{*}{$\begin{array}{ll} & \text { Discrete energy injection } \\
\text { - } & \text { Pulse width modulation (duty cycle control) } \\
\text { - } & \text { Secondary-side control } \\
\end{array}$} \\
\hline & Half-bridge MC & Figure $5 \mathrm{~b}$ & 2 bidirectional & 2 capacitors & \\
\hline & Full-bridge MC & Figure $5 c$ & 4 bidirectional & None & $\begin{array}{ll}\text { - } & \text { Discrete energy injection } \\
\text { - } & \text { Pulse width modulation (phase-shift control) } \\
\text { - Secondary-side control } & \text { Dual-side control } \\
\end{array}$ \\
\hline & Boost-derived full-bridge MC & Figure $5 e$ & 4 bidirectional & 1 inductor & $\begin{array}{ll}- & \text { Pulse width modulation } \\
\text { - } & \text { Secondary-side control } \\
& \text { Dual-side control } \\
\end{array}$ \\
\hline & Bridgeless boost & Figure $5 \mathrm{f}$ & $\begin{array}{l}2 \text { diodes, } \\
4 \text { reverse conducting }\end{array}$ & $\begin{array}{l}1 \text { inductor, } \\
1 \text { capacitor }\end{array}$ & $\begin{array}{ll}\text { - } & \text { Pulse width modulation } \\
\text { - } & \text { Secondary-side control } \\
& \text { Dual-side control } \\
\end{array}$ \\
\hline
\end{tabular}




\subsection{Single-Stage $A C-A C$ Conversion}

Matrix converters (MCs) are considered as a prominent candidate for powering the WPT systems with only single-stage power conversion. Several MCs including buck [36,37], half-bridge [30,31], and full-bridge [35] have been introduced to IPT applications in the literature. All MCs reported in [30,31,35-37] have a buck-derived configuration, as shown in Figure 5a-c, thus line-current regulation is compromised. In EV charging application, if a highly nonlinear diode-bridge rectifier is used at the battery side, there will be severe line current distortion and power factor deterioration, as explained in [70]. In [35], a secondary active full-bridge rectifier whose phase shift angle follows the line-voltage waveform is used to shape the line current. In this topology, the primary and secondary converters must be controlled synchronously in every switching cycle, which increases the implementation complexity.

In order to overcome the above issue, a boost-derived full-bridge MC (FBMC) compatible with a primary parallel-series CC compensation network is proposed in [38]. The proposed converter topology is able to shape the line current and regulate power flow through two control loops, which are similar to those of a conventional boost converter. In [39], a single-stage topology integrating bridgeless boost PFC converter and full-bridge VSI is proposed for IPT applications. The converter is operated in discontinuous conduction mode, thereby, the line current control loop is eliminated. However, in discontinuous conduction mode (DCM), the converter incurs more current stress, losses, and electromagnetic interference (EMI) problems, which is not suitable for high-power applications. Figure $5 \mathrm{~d}$ and e show the configuration of boost-derived FBMC and bridgeless boost PFC converter in IPT systems.

\section{Power Control Schemes}

Figure 6 shows the classification of power control schemes for IPT systems. Power control in IPT systems can be implemented on the primary side, secondary side, or both sides. The secondary side control is suitable for the IPT applications where multiple secondary coils are coupled to a single primary coil. In these applications, the frequency and the magnitude of primary current are fixed, and the power flow is controlled on the secondary side by an active rectifier or a back-end DC-DC converter illustrated in Figure 6 for each secondary coil [30,58,59,71-74]. These topologies are normally employed in long-power track systems where a constant track current is required to power independent secondary coils.

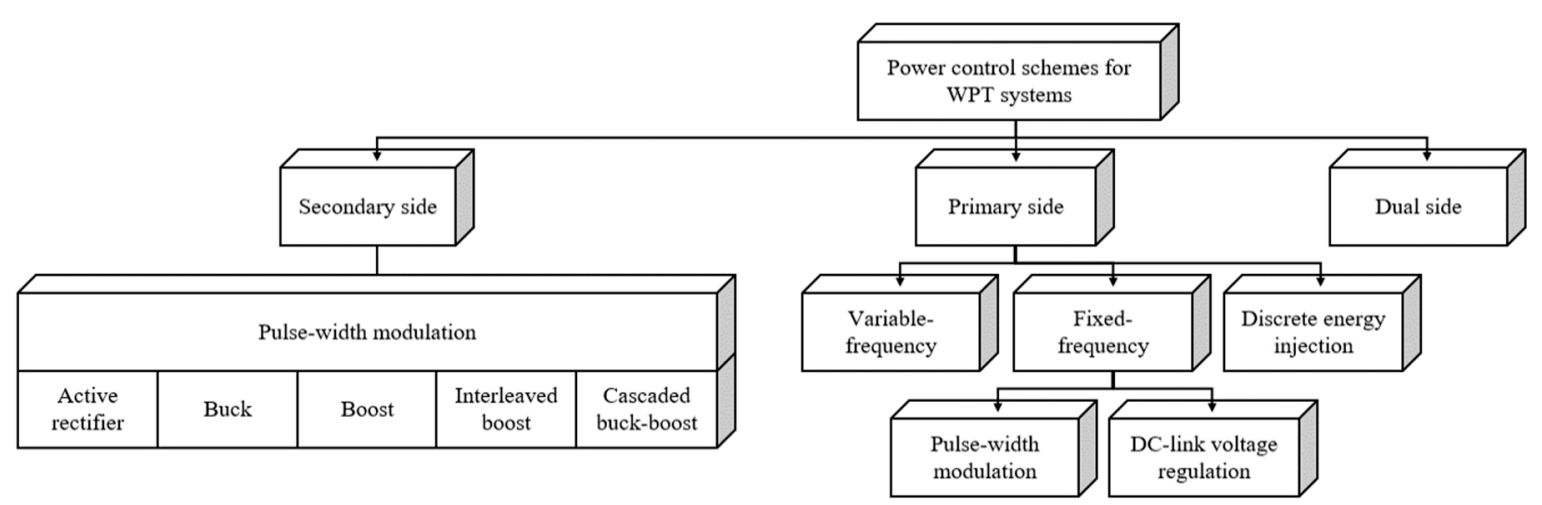

Figure 6. Classification of power control schemes for IPT applications.

However, in charging applications where only one a secondary coil is coupled to a primary coil and keeping the secondary-side configuration as simple as possible is a priority, the primary side control is selected. The primary side control can be divided into three groups: fixed frequency, variable frequency, and discrete energy injection. In fixed frequency control, the switching frequency of the inverter is kept at a constant value, which is slightly different from the primary resonant frequency to offer soft-switching operation. In order to control the power flow, the phase (phase shift control) or 
the duty cycle of the inverter switches is varied $[75,76]$. This allows the inverters to produce output voltage/current with variable pulse width. The other way to regulate the power flow with the fixed switching frequency is controlling the input DC voltage of the inverter using a front-end DC-DC converter [48]. For the variable switching frequency control scheme, the duty cycle of the gating signals is maintained constant at $50 \%$ and the switching frequency is varied to regulate the output power [49]. However, if the operating frequency is largely different from the resonant frequency, the resonant tank will incur a large circulating current, causing an efficiency drop in the overall system owing to large losses in switches and the coils. Moreover, the bifurcation phenomenon must be carefully considered in this control technique [77]. In [36], a discrete energy injection control is used for the matrix buck converter in order to control the magnitude of the primary current. The control technique reduces the switching frequency and enables soft switching. However, the zero-crossing detection of primary high-frequency current that is required to ensure the converter to be operated in zero current switching (ZCS) conditions is an implementation challenge. Moreover, current sag occurs during the zero-crossing of its single-phase input voltage, which degrades the average power transferred. The dual-side control is suitable for bidirectional IPT systems where power flow can be regulated in both directions by controlling the duty cycle of the primary and secondary converters and the phase-shift between them $[56,57,78]$. Table 2 shows the compatibility of power conversion topologies and control schemes of the IPT applications.

\section{Performance Comparison and Discussion}

In this section, the performance of a conventional dual-stage topology and two potential single-stage topologies including buck- and boost-derived FBMCs are compared regarding input power quality, current stress, voltage stress, power losses, and cost.

\subsection{Design Considerations}

The conventional dual-stage IPT charging system is illustrated in Figure 7a. At the front end, a conventional boost rectifier is used to shape the grid current and maintain a constant DC voltage $V_{d c}$ across DC-link capacitor $C_{i}$. As a bulky and costly inductor is required for the CSIs, an FBVSI is the most common choice at the primary side to generate a high-frequency voltage $\left(v_{p}\right)$ feeding the primary coil. A series-series (SS) compensation topology is used because it is simple and cost-effective, and its primary compensation is independent of the coupling coefficient and load. Moreover, the efficiency of SS compensation is high even at a low coupling coefficient [68,79]. In order to maximize the power transfer capabilities and minimize the VA rating of the primary inverter, the resonant circuits at both sides of the coupling are usually tuned to the same resonant frequency $\left(\omega_{0}\right)$ equal to the switching frequency of the inverter.

$$
\omega_{0}=\frac{1}{\sqrt{L_{p} C_{p}}}=\frac{1}{\sqrt{L_{s} C_{s}}}
$$

where $L_{p}$ and $L_{s}$ are primary and secondary coil self-inductances, respectively, and $C_{p}$ and $C_{s}$ are primary and secondary tuning capacitors, respectively.

Power regulation is conducted using the phase-shift control at the primary inverter side. Considering an ideal IPT system operating at the resonance frequency $\left(\omega_{0}\right)$, power transferred from the primary to the secondary side can be given by

$$
P_{o}=\frac{8 V_{d c} V_{b}}{\pi^{2} \omega_{0} M} \sin \pi D_{p}
$$

where $D_{p}$ is the duty cycle of the primary voltage $\left(v_{p}\right)$ and $M$ is the mutual inductance and can be calculated as

$$
M=k \sqrt{L_{p} L_{s}}
$$




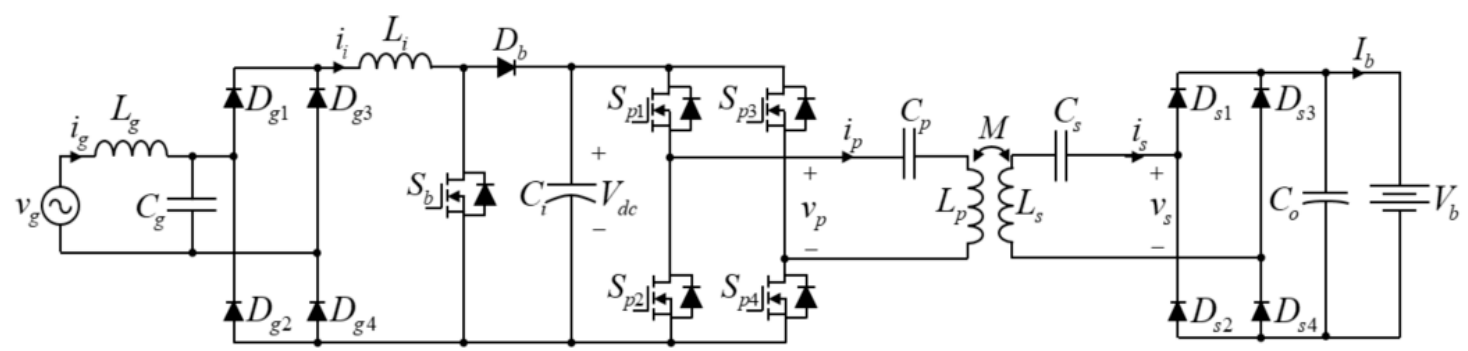

(a)
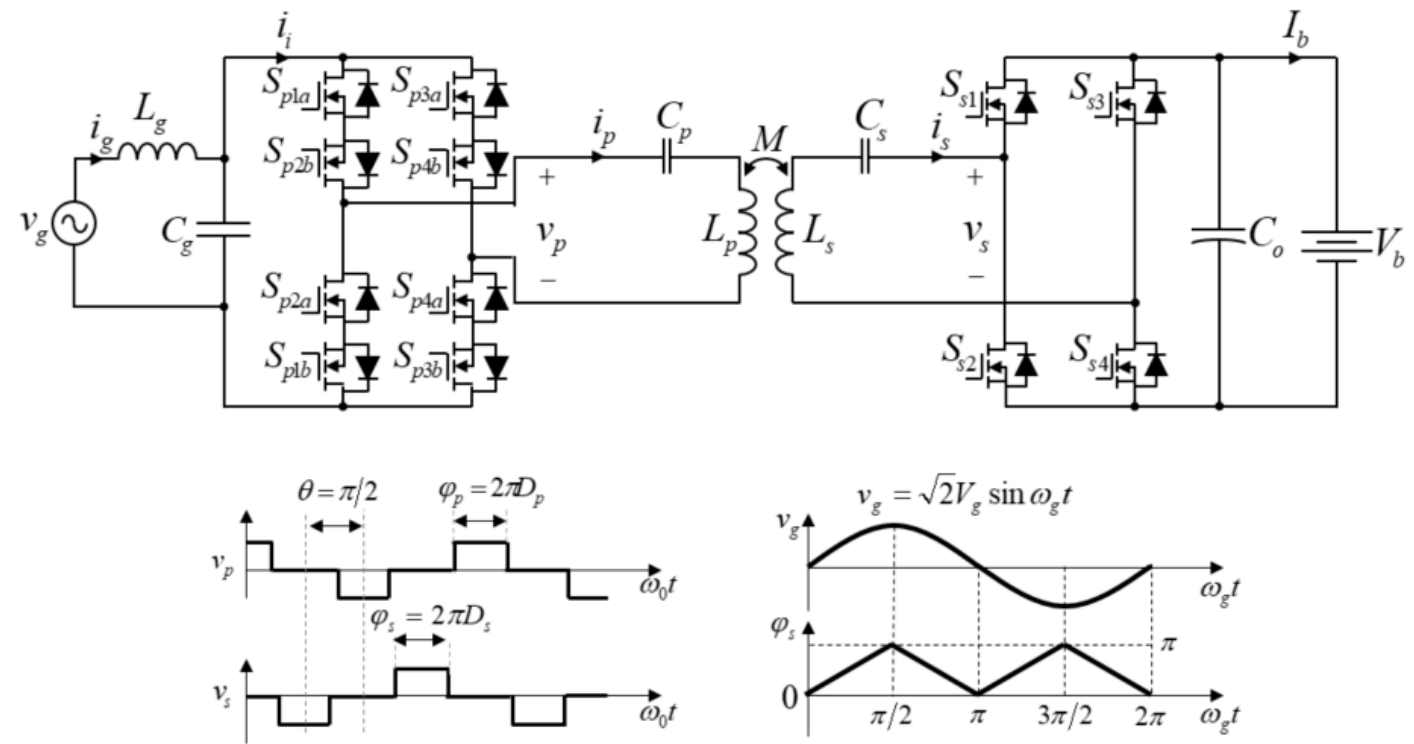

(b)

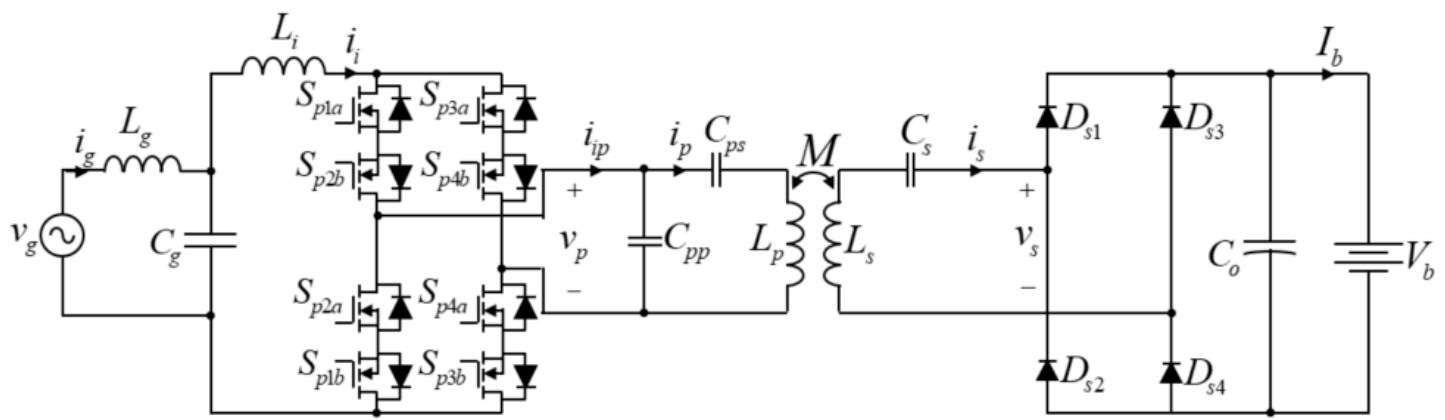

(c)

Figure 7. IPT charging system fed by (a) dual-stage power converter (PFC and full-bridge VSI), (b) buck-derived FBMC, and (c) boost-derived FBMC.

In EV wireless charging applications, the coupling coefficient $k$ may be in the range of 0.1-0.3. In a dual-stage topology, the major drawback is low power density owing to multiple conversion stages and a bulky DC-link capacitor. The reduction of the number of power conversion stages can be obtained using MCs. Figure $7 \mathrm{~b}$ shows the IPT charging system using a buck-derived FBMC. The FBMC constituted by four bidirectional switches can directly convert low frequency $(50-60 \mathrm{~Hz})$ grid voltage to resonant frequency $(85 \mathrm{kHz})$ voltage feeding the inductive coil. During the positive half cycle of the grid voltage $v_{g}$, switches $S_{p n b}(n=1,2,3,4)$ are turned on and switches $S_{p n a}$ are the phase-shift pulse-width modulation (PWM) strategy. Otherwise, during the negative half-cycle, the switches $S_{p n a}$ are kept on and switches $S_{p n b}$ are controlled by the phase-shift PWM strategy.

An active rectifier is employed in the battery side for shaping the input current. The primary and secondary converters are synchronized in every switching cycle so that primary voltage $v_{p}$ is $90^{\circ}$ 
lagging with secondary voltage $v_{s}$, and the duty cycle of the secondary voltage is controlled following grid voltage waveform to correct input current, as shown in Figure $7 \mathrm{~b}$. The power transferred is controlled by adjusting the duty cycle of the primary voltage.

$$
P_{o}=\frac{4 \sqrt{2} V_{g} V_{b}}{\pi^{2} \omega_{0} M} \sin \pi D_{p}
$$

where $V_{g}$ is the root mean square (RMS) value of the grid voltage.

Although the buck-derived FBMC-based IPT charging system removes the intermediate conversion stage, high-frequency communication is required to synchronize the PWM patterns of the primary and secondary converters in every switching cycle, which increases the control complexity. The boost-derived MC can solve the above issue. It is capable of correcting the grid current and regulating power flow through two control loops, which are similar to those of a conventional boost converter. Figure 7c shows an IPT topology fed by a boost-derived FBMC [38]. On the primary side, parallel-series $C C$ compensation is used to reduce voltage stress on the MC switches. The tuning capacitor $C_{p s}$ is selected so as to limit the maximum peak of $v_{p}$ across the converter switches. It is desirable to restrict $v_{p}$ to $0.5 \sim 0.7$ of the rating voltage of the switches [48]. The switching scheme and controller design for the boost-derived full-bridge matrix converter are described in [38]. Tables 3 and 4 show the passive component design and the switching stresses of the converter components.

Table 3. Passive component design. FB, full-bridge.

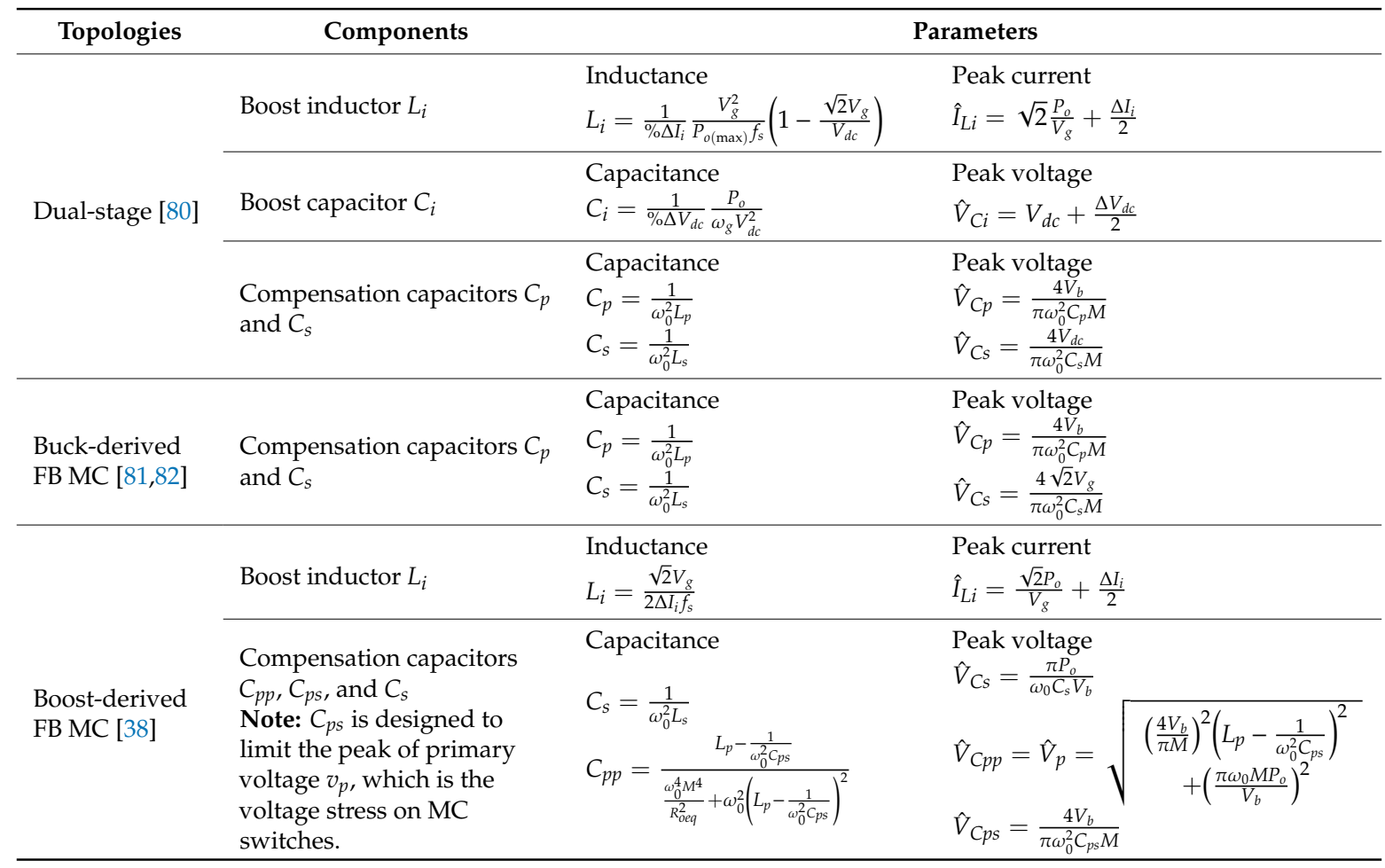


Table 4. Stress on switching devices.

\begin{tabular}{|c|c|c|c|}
\hline Topologies & Components & Current Stress & Voltage Stress \\
\hline \multirow{3}{*}{ Dual-stage } & Boost switch $S_{b}$ and diode $D_{b}$ & $\begin{array}{l}\text { Peak current } \\
\hat{I}_{S b}=\hat{I}_{D b}=\frac{\sqrt{2} P_{o}}{V_{g}}+\frac{\Delta I_{i}}{2}\end{array}$ & $\begin{array}{l}\text { Break down voltage } \\
\hat{V}_{S b}=\hat{V}_{D b}>V_{d c}+\frac{\Delta V_{d c}}{2}\end{array}$ \\
\hline & $\begin{array}{l}\text { Primary inverter switches } S_{p n} \\
(n=1,2,3,4)\end{array}$ & $\begin{array}{l}\text { Peak current } \\
\hat{I}_{S p n}=\frac{4 V_{b}}{\pi \omega_{0} M}\end{array}$ & $\begin{array}{l}\text { Break down voltage } \\
\hat{V}_{S p n}>V_{d c}+\frac{\Delta V_{d c}}{2}\end{array}$ \\
\hline & $\begin{array}{l}\text { Secondary rectifier diodes } D_{s n} \\
(n=1,2,3,4)\end{array}$ & $\begin{array}{l}\text { Peak current } \\
\hat{I}_{D s n}=\frac{4 V_{d c}}{\pi \omega_{0} M}\end{array}$ & $\begin{array}{l}\text { Break down voltage } \\
\hat{V}_{D s n}>V_{b}\end{array}$ \\
\hline \multirow[t]{2}{*}{ Buck-derived FB MC } & $\begin{array}{l}\text { Primary inverter switches } S_{p n x} \\
(n=1,2,3,4 \text { and } x=a, b)\end{array}$ & $\begin{array}{l}\text { Peak current } \\
\hat{I}_{S p n x}=\frac{4 V_{b}}{\pi \omega_{0} M}\end{array}$ & $\begin{array}{l}\text { Break down voltage } \\
\hat{V}_{S p n x}>\sqrt{2} V_{g}\end{array}$ \\
\hline & $\begin{array}{l}\text { Secondary rectifier switches } \\
S_{s n}(n=1,2,3,4)\end{array}$ & $\begin{array}{l}\text { Peak current } \\
\hat{I}_{S s n}=\frac{4 \sqrt{2} V_{g}}{\pi \omega_{0} M}\end{array}$ & $\begin{array}{l}\text { Break down voltage } \\
\hat{V}_{S s n}>V_{b}\end{array}$ \\
\hline \multirow[t]{2}{*}{ Boost-derived FB MC } & $\begin{array}{l}\text { Primary inverter switches } S_{p n x} \\
(n=1,2,3,4 \text { and } x=a, b)\end{array}$ & $\begin{array}{l}\text { Peak current } \\
\hat{I}_{S p n x}>\frac{\sqrt{2} P_{o}}{V_{g}}+\frac{\Delta I_{i}}{2}\end{array}$ & $\begin{array}{l}\text { Break down voltage } \\
\hat{V}_{S p n x}>\hat{V}_{p}\end{array}$ \\
\hline & $\begin{array}{l}\text { Secondary rectifier diodes } D_{s n} \\
(n=1,2,3,4)\end{array}$ & $\begin{array}{l}\text { Peak current } \\
\hat{I}_{D s n}>\frac{\pi P_{0}}{V_{b}}\end{array}$ & $\begin{array}{l}\text { Break down voltage } \\
\hat{V}_{D s n}>V_{b}\end{array}$ \\
\hline
\end{tabular}

\subsection{Performance Comparison}

In this section, the performance of IPT configurations is compared in terms of input power factor, input current distortion, current stress, voltage stress, power losses on converters, and normalized cost. The IPT charging systems are designed in compliance with the level 1 (WPT1) of static wireless charging standard for light-duty vehicles provided in SAE J2954 technical information report [19] with power rating $P_{o}=3.3 \mathrm{~kW}$, operating frequency $f_{s}=85 \mathrm{kHz}$, grid voltage $V_{g}=208 \mathrm{~V}$, and battery voltage $V_{b}=300-400 \mathrm{~V}$. The parameters of the charging system with each type of power conversion configuration are shown in Table 5. All the components are designed based on Tables 3 and 4. The selection of components is based on their maximum current and voltage stresses. Note that available discrete Rohm SiC MOSFETs and Schottky diodes are considered for all power conversion topologies. Moreover, $L C$ filters are used as interfaces between the grid and the charging systems to limit current harmonic injection owing to the switching power converters. The $L C$ filters are designed based on the spectrum analysis of the input current waveforms $\left(i_{i}\right)$. The details of the selected components for different power conversion stages are listed in Table 6.

Figure 8 shows the typical waveforms of IPT charging systems with different power supply topologies. It can be seen that the absence of DC-link energy storage in MC-based topologies causes a double line frequency fluctuation in transferred power. This results in a fluctuating charging current as shown in Figure $8 \mathrm{~b}$ and c. As reported in $[40-44,83,84]$, batteries can be charged by double line frequency $(100$ or $120 \mathrm{~Hz})$ current with negligible side effects on their performance. 
Table 5. Specifications of IPT charging systems.

\begin{tabular}{|c|c|c|c|c|}
\hline Topologies & Parameter & Symbol & Value & Unit \\
\hline \multirow{8}{*}{ Dual-stage } & $\begin{array}{l}\text { Primary, secondary, mutual } \\
\text { inductance }\end{array}$ & $L_{p}, L_{s}, M$ & $356,328,65$ & $\mu \mathrm{H}$ \\
\hline & Compensation capacitors & $C_{p}, C_{s}$ & 10,11 & $\mathrm{nF}$ \\
\hline & Boost inductor & $L_{i}$ & 0.215 & $\mathrm{mH}$ \\
\hline & DC-bus capacitor & $C_{i}$ & 1540 & $\mu \mathrm{F}$ \\
\hline & DC-bus voltage & $V_{d c}$ & 400 & $\mathrm{~V}$ \\
\hline & Grid inductor & $L_{g}$ & 0.215 & $\mathrm{mH}$ \\
\hline & Grid capacitor & $C_{g}$ & 0.78 & $\mu \mathrm{F}$ \\
\hline & Output capacitor & $C_{0}^{0}$ & 500 & $\mu \mathrm{F}$ \\
\hline \multirow{5}{*}{$\begin{array}{l}\text { Buck-derived } \\
\text { FBMC }\end{array}$} & $\begin{array}{l}\text { Primary, secondary, mutual } \\
\text { inductance }\end{array}$ & $L_{p}, L_{s}, M$ & $111,111,24$ & $\mu \mathrm{H}$ \\
\hline & Compensation capacitors & $C_{p}, C_{s}$ & 32,32 & $\mathrm{nF}$ \\
\hline & Grid inductor & $L_{g}$ & 0.215 & $\mathrm{mH}$ \\
\hline & Grid capacitor & $C_{g}$ & 0.78 & $\mu \mathrm{F}$ \\
\hline & Output capacitor & $C_{0}^{0}$ & 500 & $\mu \mathrm{F}$ \\
\hline \multirow{6}{*}{$\begin{array}{l}\text { Boost-derived } \\
\text { FBMC }\end{array}$} & $\begin{array}{l}\text { Primary, secondary, mutual } \\
\text { inductance }\end{array}$ & $L_{p}, L_{s}, M$ & $111,111,24$ & $\mu \mathrm{H}$ \\
\hline & Compensation capacitors & $C_{p s}, C_{p p}, C_{s}$ & $43,115,32$ & $\mathrm{nF}$ \\
\hline & Boost inductor & $L_{i}$ & 0.215 & $\mathrm{mH}$ \\
\hline & Grid inductor & $L_{g}$ & 0.036 & $\mathrm{mH}$ \\
\hline & Grid capacitor & $C_{g}$ & 0.136 & $\mu \mathrm{F}$ \\
\hline & Output capacitor & $\mathrm{C}_{0}^{0}$ & 500 & $\mu \mathrm{F}$ \\
\hline
\end{tabular}

Table 6. Main components of power conversion stages.

\begin{tabular}{lllll}
\hline Topologies & Components & Symbol & Part Number & Quantity \\
\hline & Front-end rectifier diodes & $D_{g n}{ }^{*}$ & SCS240AE2C-ND & 4 \\
& Boost diode & $D_{b}$ & SCS240AE2C-ND & 1 \\
& Boost switch & $S_{b}$ & SCT3060ALGC11-ND & 1 \\
Dual-stage & Primary inverter switches & $S_{p n}{ }^{*}$ & SCT3120ALHRC11-ND & 4 \\
& Secondary rectifier diodes & $D_{s n}{ }^{*}$ & SCS230AE2HRC-ND & 4 \\
& Boost inductor & $L_{i}$ & HF5712-561M-25AH & 2 parallel \\
& DC-bus capacitor & $C_{i}$ & LGN2X221MELC50 & 7 parallel \\
& Grid inductor & $L_{g}$ & HF5712-561M-25AH & 2 parallel \\
& Grid capacitor & $C_{g}$ & B32656T7394K000 & 2 parallel \\
\hline \multirow{5}{*}{ Buck-derived } & Primary MC switches & $S_{p n a}, S_{p n b}{ }^{*}$ & SCT3030ALGC11-ND & 8 \\
FBMC & Secondary rectifier diodes & $S_{s n}{ }^{*}$ & SCT3060ALGC11-ND & 4 \\
& Grid inductor & $L_{g}$ & HF5712-561M-25AH & 2 parallel \\
& Grid capacitor & $C_{g}$ & B32656T7394K000 & 2 parallel \\
\hline \multirow{5}{*}{ Boost-derived } & Secondary rectifier diodes & $S_{p n a}, S_{p n b}{ }^{*}$ & SCT2080KEC-ND & 8 \\
FBMC & Boost inductor & SCS240AE2C-ND & 4 \\
& Grid inductor & $L_{i}{ }^{*}$ & HF5712-561M-25AH & 2 parallel \\
& Grid capacitor & $L_{g}$ & HF467-980M-25AV & 2 parallel \\
& & $C_{g}$ & B32654A1683K000 & 2 parallel \\
\hline
\end{tabular}




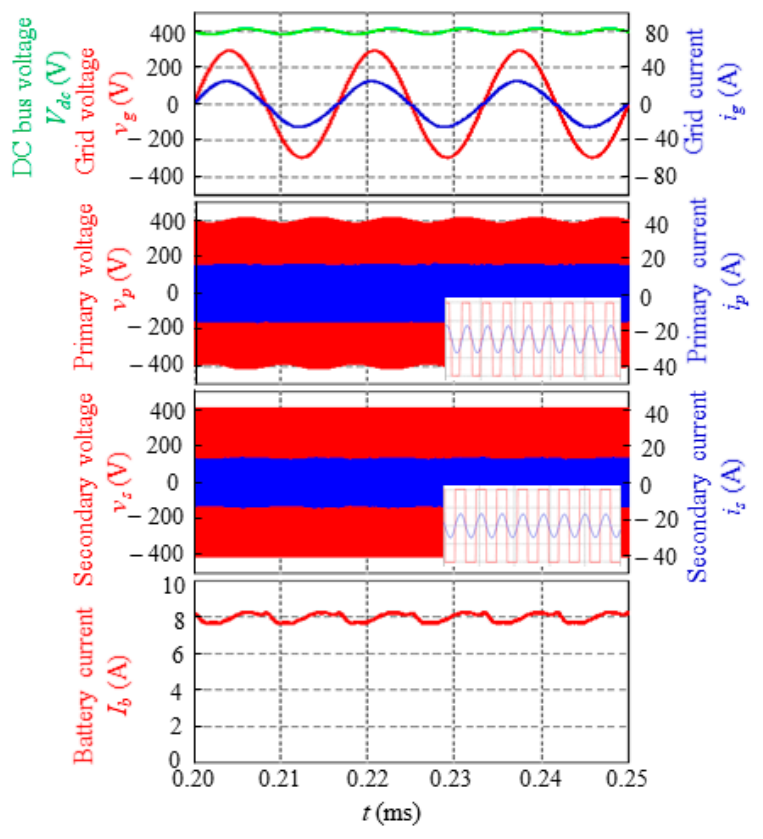

(a)

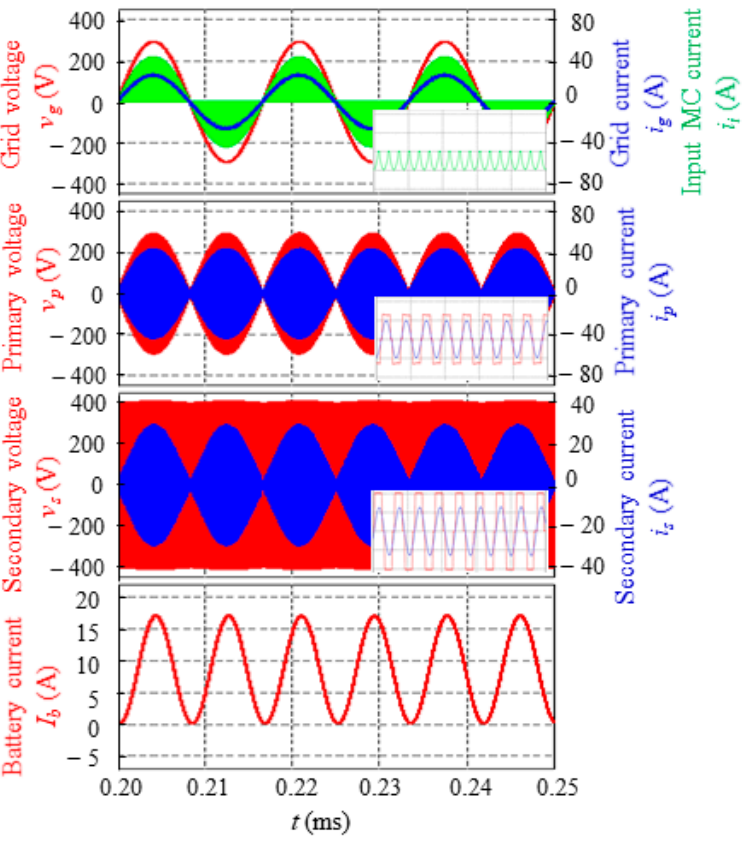

(b)

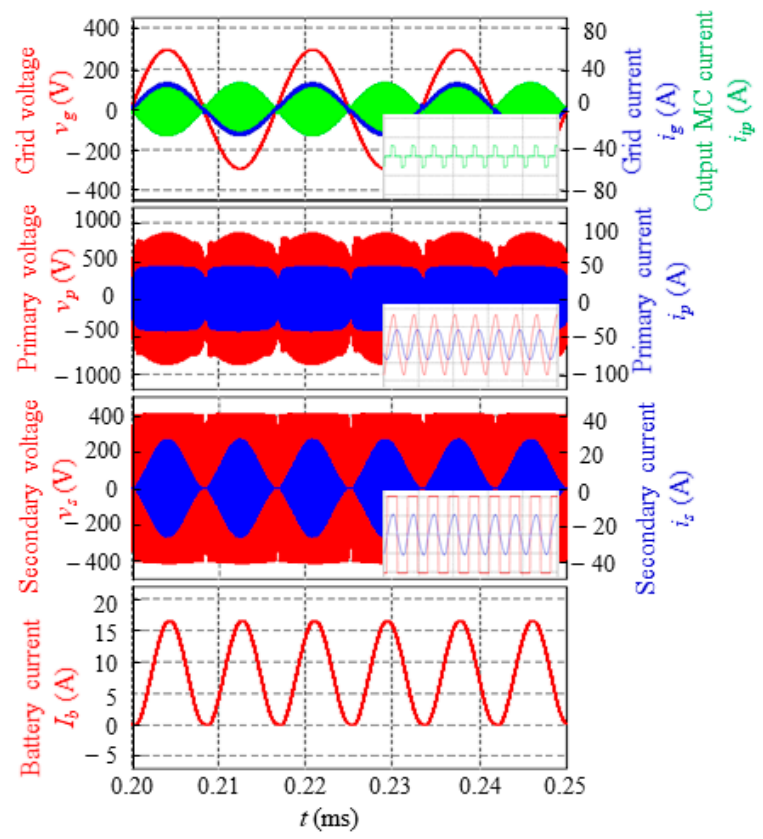

(c)

Figure 8. Simulation waveforms of IPT charging systems fed by (a) dual-stage power converter (PFC and full-bridge VSI), (b) buck-derived FBMC, and (c) boost-derived FBMC.

\subsubsection{Input Power Factor and Input Current Distortion}

An EV charger must ensure a good grid power quality with a high power factor and low current distortion. All three topologies provide sinusoidal grid currents with the power factor of 0.99 . Figure $9 \mathrm{a}$ shows total harmonic distortion (THD) of the grid current under different load conditions $(20 \%, 50 \%$, and $100 \%$ of load). It can be seen that the three topologies can be preferred in order of boost-derived FBMC, dual-stage converter, and buck-derived FBMC, regarding grid current distortion. Despite having the identical input $L C$ filter, the buck-derived FBMC injects higher current harmonics to the grid than dual-stage topology, because its input current is discontinuous. The boost-derived FBMC has 
the continuous input current with ripple frequency at a twofold switching frequency, thereby gaining the significant harmonic reduction of grid current with a smaller input filter.

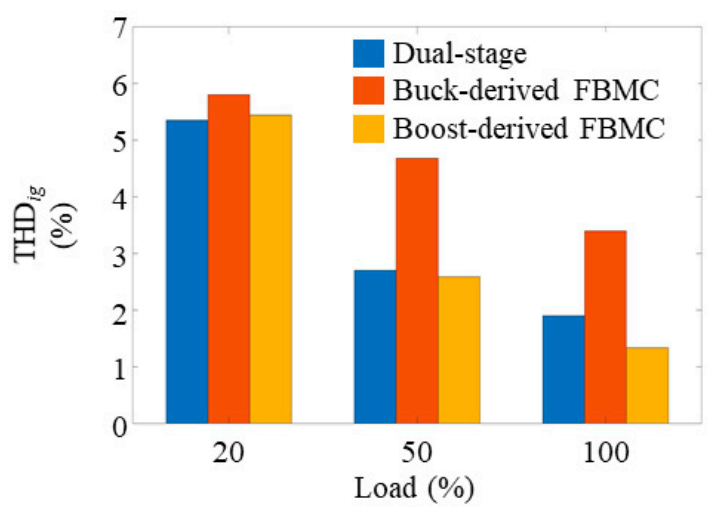

(a)

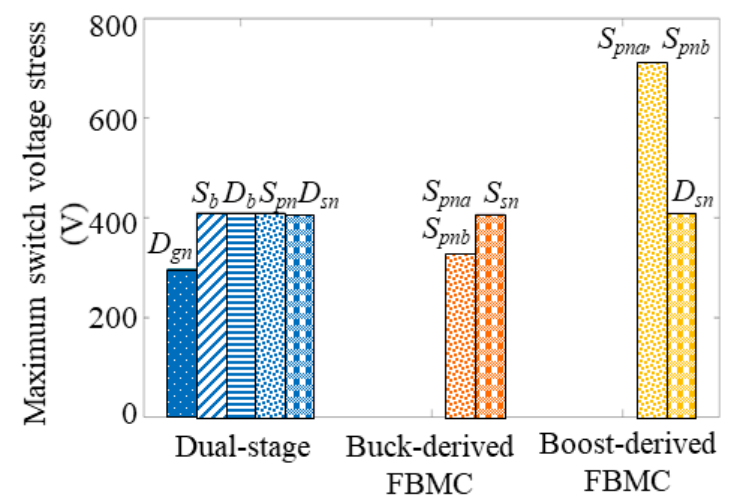

(c)

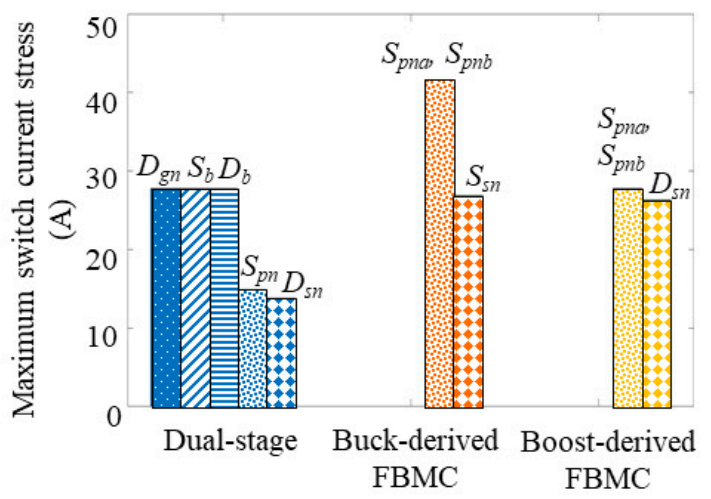

(b)

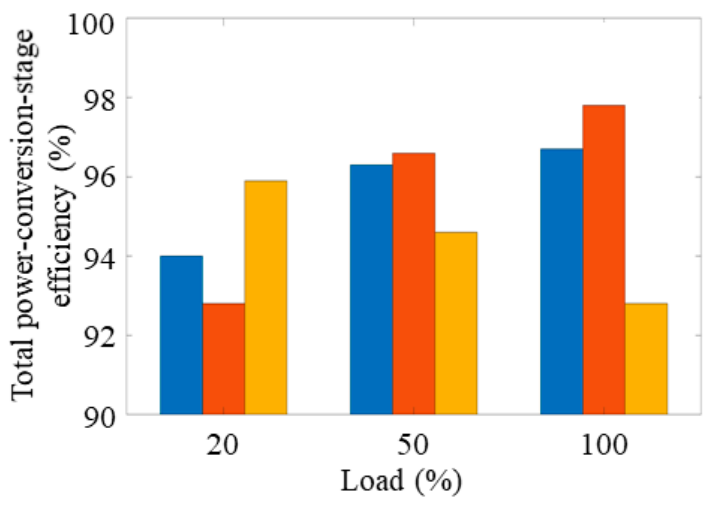

(d)

Figure 9. Performance comparison of three IPT charging systems: (a) grid current total harmonic distortion (THD), (b) switch current stress, (c) switch voltage stress, and (d) power-conversion-stage efficiency.

\subsubsection{Switching Stress}

Figure $9 \mathrm{~b}$ and $\mathrm{c}$ show the maximum current and voltage stress on the converter switches. Although the parallel-series CC compensation is used, the switches of boost-derived FBMC still suffer from high voltage stress. The buck-derived FBMC is characterized by low switch voltage stress (grid voltage peak) and high switch current stress. The dual-stage topology exhibits the lowest switch current stress in the primary inverter and secondary rectifier.

\subsubsection{Efficiency and Loss Distribution}

The losses on the conversion stages of each system are simulated and analyzed using the thermal modules in PSIM simulation. The efficiency of the power conversion stages of each system versus various output power is illustrated in Figure 9d. It is clear that the efficiency of the buck-derived FBMC system is the highest (almost $98 \%$ ) at full load conditions, but it decreases gradually to $93 \%$ at the light load conditions. In contrast, the efficiency of the boost-derived FBMC system steadily increases from $92.5 \%$ to $96 \%$ when the load decreases from $100 \%$ to $20 \%$. The dual-stage system maintains fairly high efficiency (94 96.5\%) in a wide load range.

The detailed loss distribution of the three systems is shown in Figure 10. It can be observed that the conduction losses of primary converters dominate the total losses of power conversion stages. In the dual-stage system, the conduction losses of the front-end rectifier and the primary inverter are the 
two major parts. For the single-stage systems, the conduction losses of matrix converters contribute to the largest proportions $(>60 \%)$.

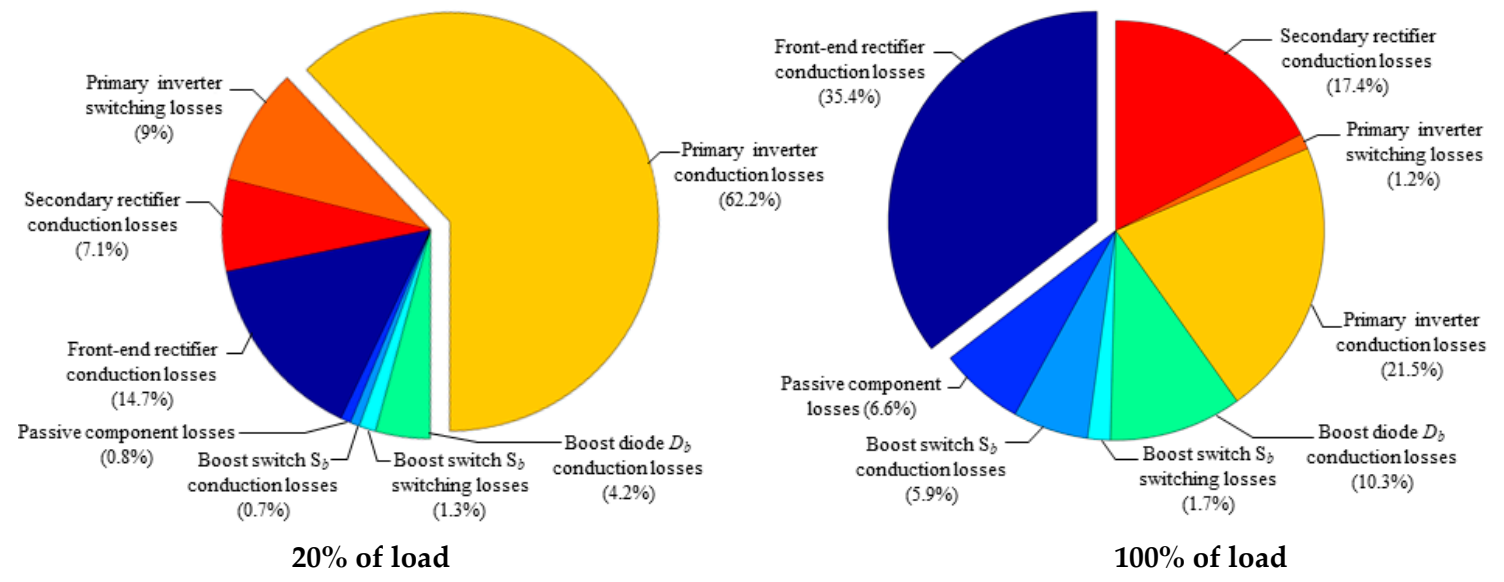

(a)

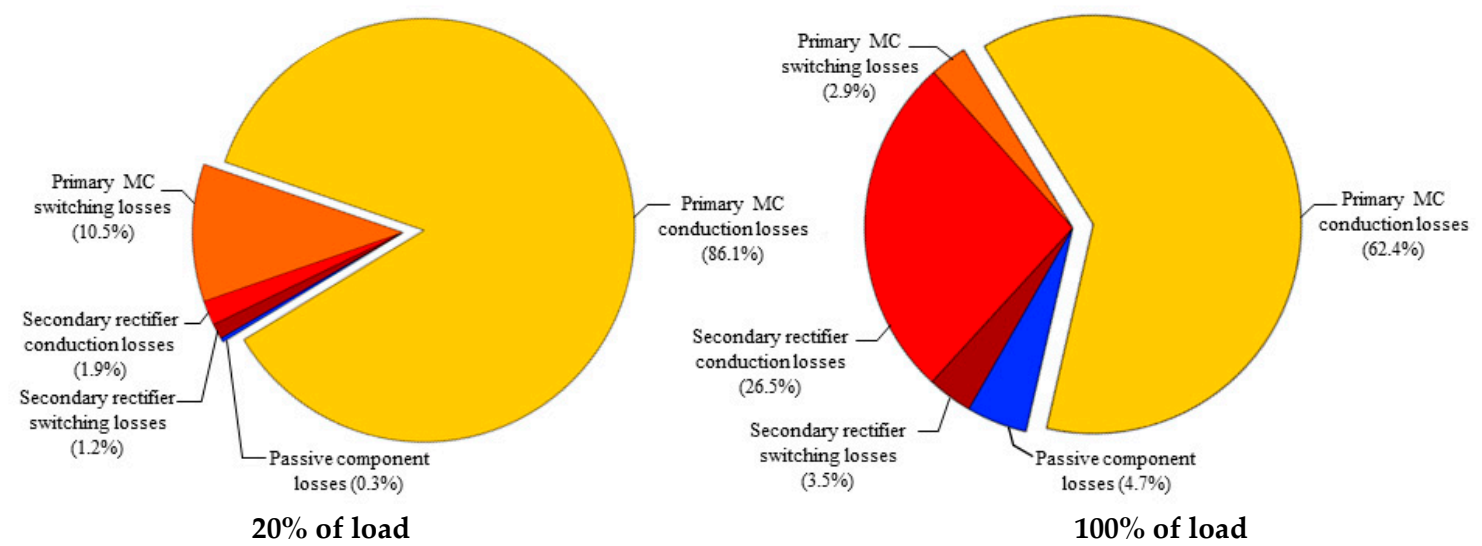

(b)

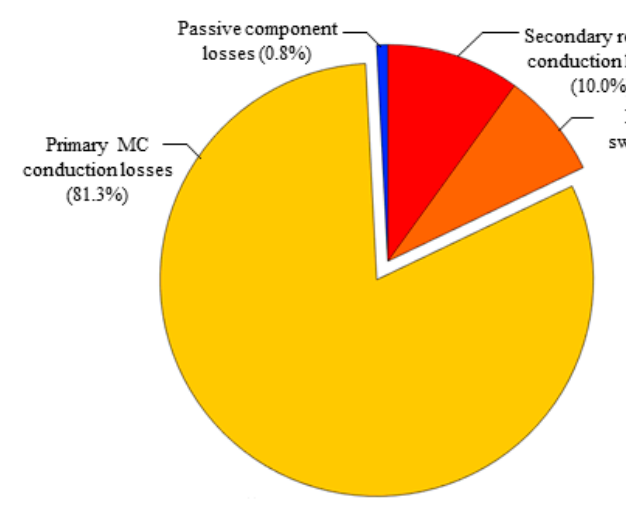

$20 \%$ of load

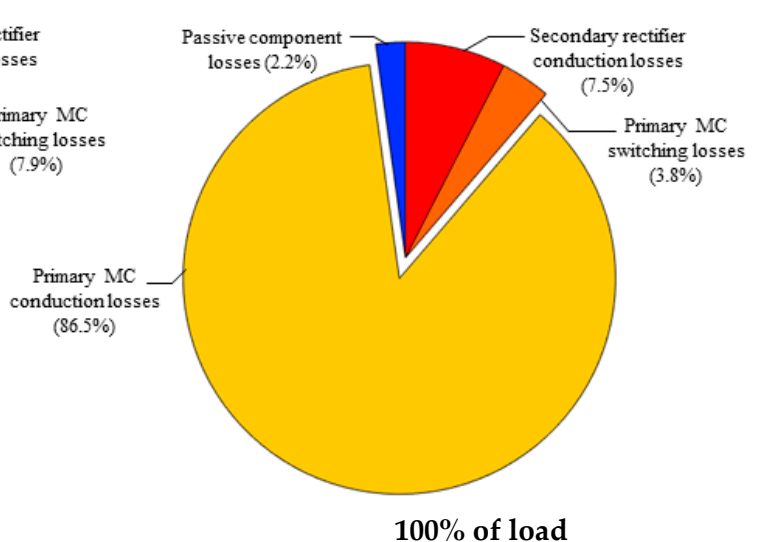

(c)

Figure 10. Loss distribution: (a) dual-stage topology, (b) buck-derived FBMC, and (c) boost-derived FBMC.

\subsubsection{Cost}

Cost is also an important quantity to evaluate the performance of a power converter. The cost structure of each charging system excluding inductive coupling coils and compensation networks is illustrated in Figure 11. The costs of the power conversion stages are calculated based on the component cost provided in Table 7 . In order to simplify the cost analysis, the auxiliary cost including 
printed circuit board (PCB) cost, cooling system cost, and housing cost is assumed to be $10 \%$ of the power converter cost. Note that MOSFETs are driven by isolated gate drivers, and MOSFETs having common-source connection utilize a common gate driver power supply to reduce the system cost. This shows that the cost of single-stage systems is lower than that of the dual-stage counterpart. The buck-derived FBMC system is the most cost-effective solution, as it presents $8.4 \%$ less cost than the dual-stage system. It is found that the costs of the passive components dominate in the dual-stage system, whereas the semiconductor devices of matrix converters occupy the largest portions in the total cost of the single-stage systems.

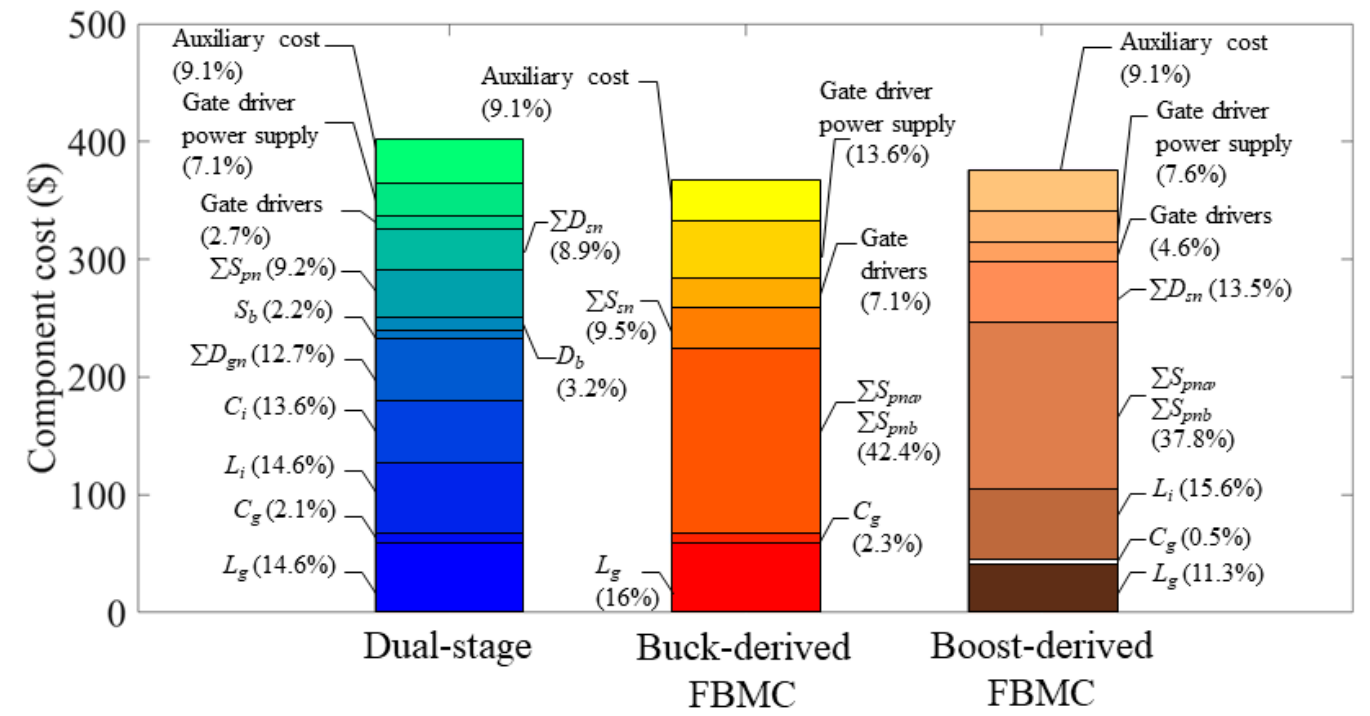

Figure 11. Component cost structure of the charging system excluding inductive coupling coils and compensation networks.

Table 7. Cost of components.

\begin{tabular}{llll}
\hline Components & Manufacturer Part Number & Rating & Unit Cost (\$) \\
\hline \multirow{2}{*}{ Diode } & SCS230AE2HRC-ND & $650 \mathrm{~V} / 30 \mathrm{~A}$ & 8.97 \\
& SCS240AE2C-ND & $650 \mathrm{~V} / 40 \mathrm{~A}$ & 12.75 \\
\hline \multirow{2}{*}{ MOSFET } & SCT3120ALHRC11-ND & $650 \mathrm{~V} / 21 \mathrm{~A}$ & 9.27 \\
& SCT3060ALGC11-ND & $650 \mathrm{~V} / 39 \mathrm{~A}$ & 8.74 \\
& SCT3030ALGC11-ND & $650 \mathrm{~V} / 70 \mathrm{~A}$ & 19.46 \\
& SCT2080KEC-ND & $1200 \mathrm{~V} / 40 \mathrm{~A}$ & 17.77 \\
\hline Gate driver IC & UCC5390SCD & $\mathrm{N} / \mathrm{A}$ & 2.16 \\
\hline \multirow{2}{*}{ Inductor driver supply } & R12P21503D & $+15 \mathrm{~V} /-3 \mathrm{~V} / 2 \mathrm{~W}$ & 7.11 \\
\hline \multirow{2}{*}{ Capacitor } & HF467-980M-25AV & $25 \mathrm{~A} / 72 \mu \mathrm{H}$ & 21.15 \\
& HF5712-561M-25AH & $25 \mathrm{~A} / 430 \mu \mathrm{H}$ & 29.25 \\
\hline
\end{tabular}

\subsection{Discussions}

From the above analysis, it can be observed that the three IPT charging systems have their own advantages and disadvantages. A comparison summary of the three IPT charging systems is shown in Figure 12, where performance indices are presented in a scale range from 1 (worst) to 3 (best). In order to evaluate the efficiencies of the three systems, their average values under all load conditions are considered. The switching stresses are assessed based on the product of the maximum current 
and voltage stresses. Figure 12 shows that the buck-derived FBMC surpasses the other counterparts with the advantages of high efficiency, cost reduction and possible power density improvement due to less component count, while the boost-derived FBMC has the greatest input current quality due to the feature of the continuous input current with ripple frequency at a twice switching frequency. The conventional dual-stage topology has the lowest stress on switching devices, and its efficiency maintains a comparable high level over wide load range. Moreover, the dual-stage converter topology is highly matured in terms of manufacturability and control as it has been developed by many manufacturers and widely used in the industry. Also, this topology allows each converter stage to be separately designed and optimized.

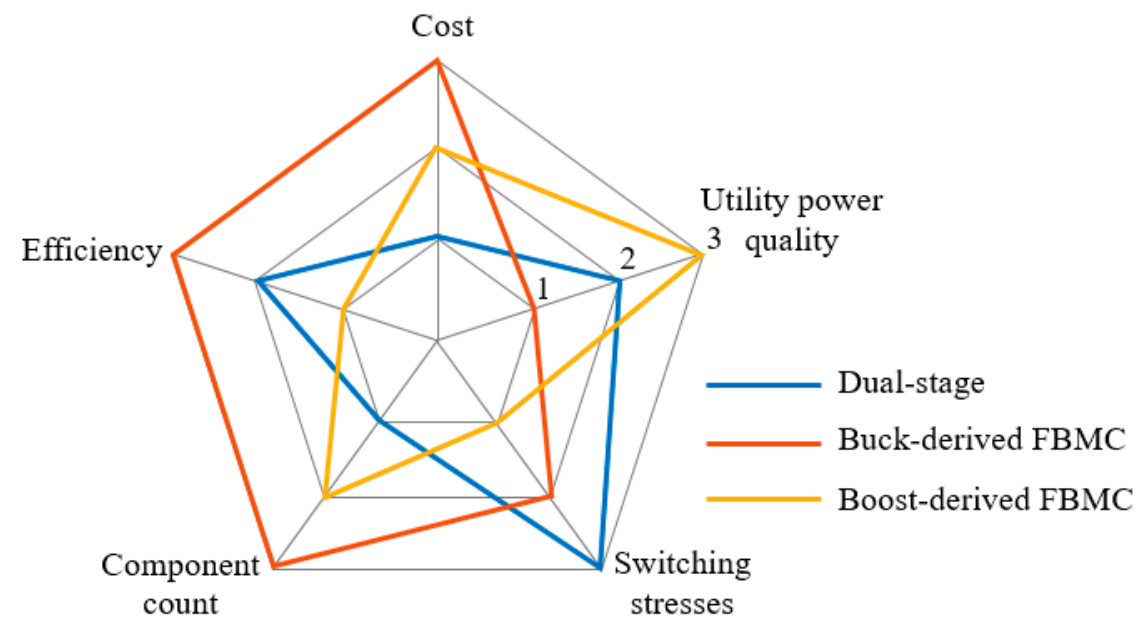

Figure 12. Comparison summary of the dual-stage and single-stage IPT charging systems.

\section{Future Trends and Opportunities}

Over the past decade, there have been significant developments in power converter topologies and control schemes for EV IPT charging. One of the important challenges is the design of high-frequency power converters for IPT to meet future requirements. Still, there is a lot of scope for further improvements to enhance the performance in terms of efficiency, power density, scalability, and reliability to promote the IPT-based systems for EV charging. Reducing power losses in power conversion from the source to the input of the coil is a vital factor in improving efficiency. One of such initiatives is to develop advanced soft-switching modulation techniques for the existing converter topologies and new reduced-switch-count converter topologies to reduce switching losses. This is expected to improve the thermal design and power density of the overall system. Several soft-switching control schemes have been reported in the literature. Generally, they can be divided into three groups: with auxiliary DC-DC converters [85-87], with variable resonant networks [88,89], and with active inverter/rectifier control [59,90-92]. However, the proposed control schemes require extra DC-DC converters or resonant components, or have an operation range limitation and high control complexity.

Direct power conversion topologies such as matrix converters can be one of the possible candidates with the elimination of life-limited bulky DC capacitors employing enhanced charging techniques like SRC charging. Another important performance enhancement is employing wide bandgap devices in the existing converter topologies or development of advanced topologies, which can operate at higher switching frequencies with low switching losses [93]. This can boost the performance of power converters in the wireless charging applications [94]. The application of gallium nitride (GaN) in IPT systems has opened up a new scope in improvement in power transfer and power density. These devices have a low voltage drop, ability to operate at the higher switching frequency, and comparatively lower thermal generation during operation, which allows for passive cooling to increase the converter power density and cost-effectiveness [95]. However, some challenges regarding the manufacturing process, packaging with higher current ratings, the gate driver design, device characterization, busbar 
layout, thermal management, and reliability need to be addressed. Therefore, much more research initiatives in the aforementioned issues could decide the power density of the converter. In addition, employing the GaN devices allows an increase in switching frequencies even at higher current standards, which improves the performance of WPT, such as transfer distance extension, higher tolerance to coil misalignment, and passive component size reduction. Furthermore, the magnetic integration can be used to integrate magnetic components of power converters, compensation networks, and coupling coils, in turn, to enhance using higher flux density material to reduce the system size and losses. One of the possible ways is the utilization of advanced materials and nanotechnology to reduce the size and weight of passive components.

In the recent days, modular power converters with fault-tolerance are demanded due to industrial requirements such as flexibility in assembly, manufacturing process, scalability and reduced mean time to failure (MTTF). Some of the possible potential candidates are multiphase parallel inverter [96], modular multilevel converter [97], parallel IPT power supply topologies [98] and extreme fast charging architectures [99] to improve the output power capability and fault tolerance for WPT systems, which can open up more research in developing advanced power topologies and fault-tolerant control schemes. Other stimulating research areas for developing technology are bidirectional power flow, integration with hybrid energy storage systems and multiple energy sources [100]. However, these areas are still under research that further attention and investigation for developing advanced multi-port converter topologies and newly advanced control schemes must comply with future charging standards to promote IPT systems for EV charging applications.

\section{Conclusions}

This paper presents an extensive overview of power conversion topologies and control schemes for IPT-based EV charging applications. The design considerations and performance evaluation of the conventional dual-stage topology and two potential single-stage topologies including buck- and boost-derived FBMCs were discussed. It is concluded that the conventional dual-stage topology has the lowest stress on switching devices, and the boost-derived FBMC provides the greatest input current quality. On the other hand, the superiorities of the buck-derived FBMC over the other topologies are high efficiency, low component count and cost. However, further investigation on IPT-based charging systems is needed including scalability to higher power levels, adoption of soft-switching technology, fault-tolerability technology, active power decoupling methods, magnetic integration, green energy based-IPT systems, multi-mode operation systems, wide bandgap device technology, high-performance advanced and non-invasive control schemes. With the continual improvements and the aforementioned advancements, IPT-based systems will definitively increase the availability and economic viability of the EVs in the near future.

Author Contributions: Conceptualization, P.S.H. and S.S.W.; Software, P.S.H.; Validation, P.S.H.; Formal Analysis, P.S.H.; Investigation, P.S.H.; Resources, P.S.H. and D.R.; Data Curation, P.S.H.; Writing Original Draft Preparation, P.S.H. and D.R.; Writing Review \& Editing, P.S.H, D.R., D.V., and S.S.W.; Visualization, P.S.H., D.R., and D.V.; Supervision, S.S.W.; Project Administration, S.S.W.; Funding Acquisition, S.S.W. All authors have read and agreed to the published version of the manuscript.

Funding: This work was supported by the Natural Sciences and Engineering Research Council (NSERC), Canada. Conflicts of Interest: The authors declare no conflict of interest.

\section{References}

1. Khaligh, A.; Dusmez, S. Comprehensive topological analysis of conductive and inductive charging solutions for plug-in electric vehicles. IEEE Trans. Veh. Technol. 2012, 61, 3475-3489. [CrossRef]

2. Wang, C.S.; Stielau, O.H.; Covic, G.A. Design considerations for acontactless electric vehicle battery charger. IEEE Trans. Ind. Electron. 2005, 52, 1308-1314. [CrossRef]

3. Hui, S.Y.R.; Ho, W.W.C. A new generation of universal contactless battery charging platform for portable consumer electronic equipment. IEEE Trans. Power Electron. 2005, 20, 620-627. [CrossRef] 
4. Daga, A.; Miller, J.M.; Long, B.R.; Kacergis, R.; Schrafel, P.; Wolgemuth, J. Electric fuel pumps for wireless power transfer: Enabling rapid growth in the electric vehicle market. IEEE Power Electron. Mag. 2017, 4, 24-35. [CrossRef]

5. Kazmierkowski, M.P.; Moradewicz, A.J. Unplugged but connected: Review of contactless energy transfer systems. IEEE Ind. Electron. Mag. 2012, 6, 47-55. [CrossRef]

6. Bosshard, R.; Kolar, J.W. Inductive power transfer for electric vehicle charging: Technical challenges and tradeoffs. IEEE Power Electron. Mag. 2016, 3, 22-30. [CrossRef]

7. Choi, S.Y.; Gu, B.W.; Jeong, S.Y.; Rim, C.T. Advances in wireless power transfer systems for roadway-powered electric vehicles. IEEE J. Emerg. Sel. Top. Power Electron. 2015, 3, 18-36. [CrossRef]

8. Ahmad, A.; Alam, M.S.; Chabaan, R. A comprehensive review of wireless charging technologies for electric vehicles. IEEE Trans. Transp. Electrific. 2018, 4, 38-63. [CrossRef]

9. Mi, C.C.; Buja, G.; Choi, S.Y.; Rim, C.T. Modern advances in wireless power transfer systems for roadway powered electric vehicles. IEEE Trans. Ind. Electron. 2016, 63, 6533-6545. [CrossRef]

10. Covic, G.A.; Boys, J.T. Modern trends in inductive power transfer for transportation applications. IEEE J. Emerg. Sel. Top. Power Electron. 2013, 1, 28-41. [CrossRef]

11. Roes, M.G.L.; Duarte, J.L.; Hendrix, M.A.M.; Lomonova, E.A. Acoustic energy transfer: A review. IEEE Trans. Ind. Electron. 2013, 60, 242-248. [CrossRef]

12. Hu, Y.; Zhang, X.; Yang, J.; Jiang, Q. Transmitting electric energy through a metal wall by acoustic waves using piezoelectric transducers. IEEE Trans. Ultrason. Ferroelectr. Freq. Control 2003, 50, 773-781. [CrossRef] [PubMed]

13. Chow, E.Y. Wireless powering and the study of RF propagation through ocular tissue for development of implantable sensors. IEEE Trans. Antennas Propag. 2011, 59, 2379-2387. [CrossRef]

14. Sasaki, S.; Tanaka, K.; Maki, K.I. Microwave power transmission technologies for solar power satellites. Proc. IEEE 2013, 101, 1438-1447. [CrossRef]

15. Wang, N.; Zhu, Y.; Wei, W.; Chen, J.; Liu, S.; Li, P.; Wen, Y. One-to-multipoint laser remote power supply system for wireless sensor networks. IEEE Sens. J. 2012, 12, 389-396. [CrossRef]

16. Sahai, A.; Graham, D. Optical wireless power transmission at long wavelengths. In Proceedings of the International Conference on Space Optical Systems and Applications, Santa Monica, CA, USA, 11-13 May 2011; pp. 164-170.

17. Kline, M.; Izyumin, I.; Boser, B.; Sanders, S. Capacitive power transfer for contactless charging. In Proceedings of the 26th Annual IEEE Applied Power Electronics Conference and Exposition, Fort Worth, TX, USA, 6-11 March 2011; pp. 1398-1404.

18. Covic, G.A.; Boys, J.T. Inductive Power Transfer. Proc. IEEE 2013, 101, 1276-1289. [CrossRef]

19. J2954: Wireless Power Transfer for Light-Duty Plug-In/Electric Vehicles and Alignment Methodology; SAE International: Warrendale, PA, USA, 2016.

20. Musavi, F.; Eberle, W. Overview of wireless power transfer technologies for electric vehicle battery charging. IET Power Electron. 2014, 7, 60-66. [CrossRef]

21. Siqi, L.; Mi, C.C. Wireless power transfer for electric vehicle applications. IEEE J. Emerg. Sel. Top. Power Electron. 2015, 3, 4-17. [CrossRef]

22. J1772: SAE Electric Vehicle and Plug in Hybrid Electric Vehicle Conductive Charge Coupler; SAE International: Warrendale, PA, USA, 2017.

23. Mohamed, A.A.S.; Lashway, C.R.; Mohammed, O. Modeling and feasibility analysis of quasi-dynamic WPT system for EV applications. IEEE Trans. Transp. Electrif. 2017, 3, 343-353. [CrossRef]

24. Cirimele, V.; Diana, M.; Bellotti, F.; Berta, R.; Sayed, N.E.; Kobeissi, A.; Guglielmi, P.; Ruffo, R.; Khalilian, M.; Ganga, A.L.; et al. The fabric ICT platform for managing wireless dynamic charging road lanes. IEEE Trans. Veh. Technol. 2020, 69, 2501-2512. [CrossRef]

25. Miller, J.M.; Onar, O.C.; White, C.; Campbell, S.; Coomer, C.; Seiber, L.; Sepe, R.; Steyerl, A. Demonstrating dynamic wireless charging of an electric vehicle: The benefit of electrochemical capacitor smoothing. IEEE Power Electron. Mag. 2014, 1, 12-24. [CrossRef]

26. Cirimele, V.; Diana, M.; Freschi, F.; Mitolo, M. Inductive power transfer for automotive applications: State-of-the-art and future trends. IEEE Trans. Ind. Appl. 2018, 54, 4069-4079. [CrossRef] 
27. Everts, J.; Krismer, F.; Keybus, J.V.d.; Driesen, J.; Kolar, J.W. Optimal ZVS modulation of single-phase single-stage bidirectional DAB AC-DC converters. IEEE Trans. Power Electron. 2014, 29, 3954-3970. [CrossRef]

28. Bosshard, R.; Kolar, J.W. All-SiC 9.5 kW/dm3 On-Board Power Electronics for 50 kW/85 kHz Automotive IPT System. IEEE J. Emerg. Sel. Topics Power Electron. 2017, 5, 419-431. [CrossRef]

29. Kolar, R.B.a.J.W. Multi-objective optimization of $50 \mathrm{~kW} / 85 \mathrm{kHz}$ IPT system for public transport. IEEE J. Emerg. Sel. Topics Power Electron. 2016, 4, 1370-1382.

30. Koushki, B.; Jain, P.; Bakhshai, A. A bi-directional AC-DC converter for electric vehicle with no electrolytic capacitor. In Proceedings of the IEEE 7th International Symposium on Power Electronics for Distributed Generation Systems (PEDG), Vancouver, BC, Canada, 27-30 June 2016; pp. 1-8.

31. Shin, C.J.; Lee, J.Y. An electrolytic capacitor-less bi-directional EV on-board charger using harmonic modulation technique. IEEE Trans. Power Electron. 2014, 29, 5195-5203. [CrossRef]

32. Moghaddami, M.; Anzalchi, A.; Sarwat, A.I. Single-stage three-phase AC-AC matrix converter for inductive power transfer systems. IEEE Trans. Ind. Electron. 2016, 63, 6613-6622. [CrossRef]

33. Bac, N.X.; Vilathgamuwa, D.M.; Madawala, U.K. A SiC-based matrix converter topology for inductive power transfer system. IEEE Trans. Power Electron. 2014, 29, 4029-4038.

34. Ecklebe, A.; Lindemann, A.; Schulz, S. Bidirectional switch commutation for a matrix converter supplying a series resonant load. IEEE Trans. Power Electron. 2009, 24, 1173-1181. [CrossRef]

35. Weerasinghe, S.; Madawala, U.K.; Thrimawithana, D.J. A matrix converter-based bidirectional contactless grid interface. IEEE Trans. Power Electron. 2017, 32, 1755-1766. [CrossRef]

36. Li, H.L.; Hu, A.P.; Covic, G.A. A direct AC-AC converter for inductive power-transfer systems. IEEE Trans. Power Electron. 2012, 27, 661-668. [CrossRef]

37. Sulistyono, W.; Enjeti, P. A series resonant AC-to-DC rectifier with high-frequency isolation. IEEE Trans. Power Electron. 1995, 10, 784-790. [CrossRef]

38. Samanta, S.; Rathore, A.K. A new inductive power transfer topology using direct ac-ac converter with active source current waveshaping. IEEE Trans. Power Electron. 2018, 33, 5565-5577. [CrossRef]

39. Liu, J.; Chan, K.W.; Chung, C.Y.; Chan, N.H.L.; Liu, M.; Xu, W. Single-stage wireless-power-transfer resonant converter with boost bridgeless power-factor-correction rectifier. IEEE Trans. Ind. Electron. 2018, 65, 2145-2155. [CrossRef]

40. Kwon, M.; Choi, S. An electrolytic capacitorless bidirectional EV charger for V2G and V2H applications. IEEE Trans. Power Electron. 2017, 32, 6792-6799. [CrossRef]

41. Prasad, R.; Namuduri, C.; Kollmeyer, P. Onboard unidirectional automotive G2V battery charger using sine charging and its effect on Li-ion batteries. In Proceedings of the IEEE Energy Conversion Congress and Exposition, Montreal, QC, Canada, 20-24 September 2015; pp. 6299-6305.

42. Beh, H.Z.; Covic, G.A.; Boys, J.T. Effects of pulse and DC charging on lithium iron phosphate (LiFePO4) batteries. In Proceedings of the IEEE Energy Conversion Congress and Exposition, Denver, CO, USA, 15-19 September 2013; pp. 315-320.

43. Jeong, S.; Jeong, Y.; Kwon, J.; Kwon, B. A soft-switching single-stage converter with high efficiency for a 3.3-kW on-board charger. IEEE Trans. Ind. Electron. 2019, 66, 6959-6967. [CrossRef]

44. Xue, L.; Shen, Z.; Boroyevich, D.; Mattavelli, P.; Diaz, D. Dual active bridge-based battery charger for plug-in hybrid electric vehicle with charging current containing low frequency ripple. IEEE Trans. Power Electron. 2015, 30, 7299-7307. [CrossRef]

45. Chen, L.; Wu, S.; Shieh, D.; Chen, T. Sinusoidal-ripple-current charging strategy and optimal charging frequency study for Li-ion batteries. IEEE Trans. Ind. Electron. 2013, 60, 88-97. [CrossRef]

46. Singh, B.; Singh, B.N.; Chandra, A.; Al-Haddad, K.; Pandey, A.; Kothari, D.P. A review of single-phase improved power quality AC-DC converters. IEEE Trans. Ind. Electron. 2003, 50, 962-981. [CrossRef]

47. Singh, B.; Singh, B.N.; Chandra, A.; Al-Haddad, K.; Pandey, A.; Kothari, D.P. A review of three-phase improved power quality AC-DC converters. IEEE Trans. Ind. Electron. 2004, 51, 641-660. [CrossRef]

48. Kamineni, A.; Neath, M.J.; Covic, G.A.; Boys, J.T. A mistuning-tolerant and controllable power supply for roadway wireless power systems. IEEE Trans. Power Electron. 2017, 32, 6689-6699. [CrossRef]

49. Si, P.; Hu, A.P.; Malpas, S.; Budgett, D. A frequency control method for regulating wireless power to implantable devices. IEEE Trans. Biomed. Circuits Syst. 2008, 2, 22-29. [CrossRef] [PubMed] 
50. Green, A.W.; Boys, J.T. 10 kHz inductively coupled power transfer-concept and control. In Proceedings of the IET 5th International Conference on Power Electronics and Variable-Speed Drives, London, UK, 26-28 October 1994; pp. 694-699.

51. Tian, J.; Hu, A.P. A DC-voltage-controlled variable capacitor for stabilizing the ZVS frequency of a resonant converter for wireless power transfer. IEEE Trans. Power Electron. 2017, 32, 2312-2318. [CrossRef]

52. Kamineni, A.; Covic, G.A.; Boys, J.T. Self-tuning power supply for inductive charging. IEEE Trans. Power Electron. 2017, 32, 3467-3479. [CrossRef]

53. Samanta, S.; Rathore, A.K.; Thrimawithana, D.J. Bidirectional current-fed half-bridge (C) (LC)-(LC) configuration for inductive wireless power transfer system. IEEE Trans. Ind. Appl. 2017, 53, 4053-4062. [CrossRef]

54. Samanta, S.; Rathore, A.K. Wireless power transfer technology using full-bridge current-fed topology for medium power applications. IET Power Electron. 2016, 9, 1903-1913. [CrossRef]

55. Samanta, S.; Rathore, A.K. A new current-fed CLC transmitter and LC receiver topology for inductive wireless power transfer application: Analysis, design, and experimental results. IEEE Trans. Transp. Electrif. 2015, 1, 357-368. [CrossRef]

56. Twiname, R.P.; Thrimawithana, D.J.; Madawala, U.K.; Baguley, C.A. A dual-active bridge topology with a tuned CLC network. IEEE Trans. Power Electron. 2015, 30, 6543-6550. [CrossRef]

57. Thrimawithana, D.J.; Madawala, U.K. A generalized steady-state model for bidirectional IPT systems. IEEE Trans. Power Electron. 2013, 28, 4681-4689. [CrossRef]

58. Asa, E.; Colak, K.; Czarkowski, D. Analysis of a CLL resonant converter with semi-bridgeless active rectifier and hybrid control. IEEE Trans. Ind. Electron. 2015, 62, 6877-6886. [CrossRef]

59. Colak, K.; Asa, E.; Bojarski, M.; Czarkowski, D.; Onar, O.C. A novel phase-shift control of semibridgeless active rectifier for wireless power transfer. IEEE Trans. Power Electron. 2015, 30, 6288-6297. [CrossRef]

60. Nam, I.I.; Dougal, R.A.; Santi, E. Novel unity-gain frequency tracking control of series-series resonant converter to improve efficiency and receiver positioning flexibility in wireless charging of portable electronics. IEEE Trans. Ind. Appl. 2015, 51, 385-397. [CrossRef]

61. Madawala, U.K.; Thrimawithana, D.J. A bidirectional inductive power interface for electric vehicles in V2G systems. IEEE Trans. Ind. Electron. 2011, 58, 4789-4796. [CrossRef]

62. Miller, J.M.; Onar, O.C.; Chinthavali, M. Primary-side power flow control of wireless power transfer for electric vehicle charging. IEEE J. Emerg. Sel. Top. Power Electron. 2015, 3, 147-162. [CrossRef]

63. Buja, G.; Bertoluzzo, M.; Mude, K.N. Design and experimentation of WPT charger for electric city car. IEEE Trans. Ind. Electron. 2015, 62, 7436-7447. [CrossRef]

64. Bavastro, D.; Canova, A.; Cirimele, V.; Freschi, F.; Giaccone, L.; Guglielmi, P.; Repetto, M. Design of wireless power transmission for a charge while driving system. IEEE Trans. Magn. 2014, 50, 965-968. [CrossRef]

65. Aditya, K.; Williamson, S.S.; Sood, V.K. Impact of zero-voltage switching on efficiency and power transfer capability of a series-series compensated IPT system. In Proceedings of the IEEE Transportation Electrification Conference (ITEC-India 2017), Pune, India, 13-15 December 2017; pp. 1-7.

66. Aditya, K.; Sood, V.K. Design of $3.3 \mathrm{~kW}$ wireless battery charger for electric vehicle application considering bifurcation. In Proceedings of the IEEE Electrical Power and Energy Conference (EPEC 2017), Saskatoon, SK, Canada, 22-25 October 2017; pp. 1-6.

67. Aditya, K.; Williamson, S.S. A review of optimal conditions for achieving maximum power output and maximum efficiency for a series-series resonant inductive link. IEEE Trans. Transp. Electrif. 2017, 3, 303-311. [CrossRef]

68. Patil, D.; McDonough, M.K.; Miller, J.M.; Fahimi, B.; Balsara, P.T. Wireless power transfer for vehicular applications: Overview and challenges. IEEE Trans. Transp. Electrif. 2018, 4, 3-37. [CrossRef]

69. Yao, Y.; Wang, Y.; Liu, X.; Lin, F.; Xu, D.G. A novel parameter tuning method for double-sided LCL compensated WPT system with better comprehensive performance. IEEE Trans. Power Electron. 2018, 33, 8525-8536. [CrossRef]

70. Boys, J.T.; Huang, C.Y.; Covic, G.A. Single-phase unity power-factor inductive power transfer system. In Proceedings of the IEEE Power Electronics Specialists Conference, Rhodes, Greece, 15-19 June 2008; pp. 3701-3706.

71. Keeling, N.A.; Covic, G.A.; Boys, J.T. A unity-power-factor IPT pickup for high-power applications. IEEE Trans. Ind. Electron. 2010, 57, 744-751. [CrossRef] 
72. Colak, K.; Bojarski, M.; Asa, E.; Czarkowski, D. A constant resistance analysis and control of cascaded buck and boost converter for wireless EV chargers. In Proceedings of the Applied Power Electronics Conference and Exposition (APEC), Charlotte, NC, USA, 15-19 March 2015; pp. 3157-3161.

73. Colak, K.; Asa, E.; Bojarski, M.; Czarkowski, D. A novel common mode multi-phase half-wave semi-synchronous rectifier for inductive power transfer applications. In Proceedings of the IEEE Transportation Electrification Conference and Expo (ITEC), Dearborn, MI, USA, 14-17 June 2015; pp. 1-6.

74. Fu, M.; Ma, C.; Zhu, X. A cascaded boost-buck converter for high-efficiency wireless power transfer systems. IEEE Trans. Ind. Inform. 2014, 10, 1972-1980. [CrossRef]

75. Aditya, K.; Williamson, S.S. Comparative study on primary side control strategies for series-series compensated inductive power transfer system. In Proceedings of the IEEE 25th International Symposium on Industrial Electronics (ISIE), Santa Clara, CA, USA, 8-10 June 2016; pp. 811-816.

76. Li, H.L. High Frequency Power Converters Based on Energy Injection Control for IPT Systems. Ph.D. Thesis, Department of Electrical and Computer Engineering, University of Auckland, Auckland, New Zealand, 2011.

77. Wang, C.S.; Covic, G.A.; Stielau, O.H. Power transfer capability and bifurcation phenomena of loosely coupled inductive power transfer systems. IEEE Trans. Ind. Electron. 2004, 51, 148-157. [CrossRef]

78. Weearsinghe, S.; Thrimawithana, D.J.; Madawala, U.K. Modeling bidirectional contactless grid interfaces with a soft DC-link. IEEE Trans. Power Electron. 2015, 30, 3528-3541. [CrossRef]

79. Yeo, T.D.; Kwon, D.; Khang, S.T.; Yu, J.W. Design of maximum efficiency tracking control scheme for closed-loop wireless power charging system employing series resonant tank. IEEE Trans. Power Electron. 2017, 32, 471-478. [CrossRef]

80. Aditya, K.; Williamson, S.S. Design guidelines to avoid bifurcation in a series-series compensated inductive power transfer system. IEEE Trans. Ind. Electron. 2019, 66, 3973-3982. [CrossRef]

81. Mohamed, A.A.S.; Berzoy, A.; de Almeida, F.G.N.; Mohammed, O. Modeling and assessment analysis of various compensation topologies in bidirectional IWPT system for EV applications. IEEE Trans. Ind. Appl. 2017, 53, 4973-4984. [CrossRef]

82. Kalra, G.R.; Huang, C.Y.; Thirmawithana, D.J.; Madawala, U.K.; Neuburger, M. A comparative study on grid-integration techniques used in bi-directional IPT based V2G applications. In Proceedings of the IEEE 2nd Annual Southern Power Electronics Conference (SPEC), Auckland, New Zealand, 5-8 December 2016; pp. 1-6.

83. Rosekeit, M.; Broeck, C.; Doncker, R.W.D. Dynamic control of a dual active bridge for bidirectional ac charging. In Proceedings of the IEEE International Conference on Industrial Technology, Seville, Spain, 17-19 March 2015; pp. 2085-2091.

84. Bala, S.; Tengner, T.; Rosenfeld, P.; Delince, F. The effect of low frequency current ripple on the performance of a Lithium Iron Phosphate (LFP) battery energy storage system. In Proceedings of the IEEE Energy Conversion Congress and Exposition, Raleigh, NC, USA, 15-20 September 2012; pp. 3485-3492.

85. Gunji, D.; Imura, T.; Fujimoto, H. Operating point setting method for wireless power transfer with constant voltage load. In Proceedings of the IEEE IECON 2015-41st Annual Conference, Yokohama, Japan, 9-12 November 2015; pp. 881-886.

86. Yang, Y.; Zhong, W.; Kiratipongvoot, S.; Tan, S.; Hui, S.Y.R. Dynamic improvement of series-series compensated wireless power transfer systems using discrete sliding mode control. IEEE Trans. Power Electron. 2018, 33, 6351-6360. [CrossRef]

87. Li, H.; Li, J.; Wang, K.; Chen, W.; Yang, X. A maximum efficiency point tracking control scheme for wireless power transfer systems using magnetic resonant coupling. IEEE Trans. Power Electron. 2015, 30, 3998-4008. [CrossRef]

88. Qu, X.; Han, H.; Wong, S.-C.; Tse, C.K.; Chen, W. Hybrid IPT topologies with constant current or constant voltage output for battery charging applications. IEEE Trans. Power Electron. 2015, 30, 6329-6337. [CrossRef]

89. Chen, Y.; Kou, Z.; Zhang, Y.; He, Z.; Mai, R.; Cao, G. Hybrid topology with configurable charge current and charge voltage output-based WPT charger for massive electric bicycles. IEEE J. Emerg. Sel. Top. Power Electron. 2018, 6, 1581-1594. [CrossRef]

90. Jiang, Y.; Wang, L.; Wang, Y.; Liu, J.; Li, X.; Ning, G. Analysis, design, and implementation of accurate ZVS angle control for EV battery charging in wireless high-power transfer. IEEE Trans. Ind. Electron. 2019, 66, 4075-4085. [CrossRef] 
91. Mishima, T.; Morita, E. High-frequency bridgeless rectifier based ZVS multiresonant converter for inductive power transfer featuring high-voltage GaN-HFET. IEEE Trans. Ind. Electron. 2017, 64, 9155-9164. [CrossRef]

92. Li, Y.; Hu, J.; Chen, F.; Li, Z.; He, Z.; Mai, R. Dual-phase-shift control scheme with current-stress and efficiency optimization for wireless power transfer systems. IEEE Trans. Circuits Syst. I Regul. Pap. 2018, 65, 3110-3121. [CrossRef]

93. Zhao, C.; Trento, B.; Jiang, L.; Jones, E.A.; Liu, B.; Zhang, Z.; Costinett, D.; Wang, F.; Tolbert, L.M.; Jansen, J.F.; et al. Design and implementation of a GaN-based, 100-kHz, 102-W/in3 single-phase inverter. IEEE J. Emerg. Sel. Top. Power Electron. 2016, 4, 824-840. [CrossRef]

94. Cai, A.Q.; Siek, L. A 2-kW, 95\% efficiency inductive power transfer system using Gallium Nitride gate injection transistors. IEEE J. Emerg. Sel. Top. Power Electron. 2017, 5, 458-468. [CrossRef]

95. Jones, E.A.; Wang, F.F.; Costinett, D. Review of commercial GaN power devices and GaN-based converter design challenges. IEEE J. Emerg. Sel. Top. Power Electron. 2016, 4, 707-719. [CrossRef]

96. Deng, Q.; Liu, J.; Czarkowski, D.; Hu, W.; Zhou, H. An inductive power transfer system supplied by a multiphase parallel inverter. IEEE Trans. Ind. Electron. 2017, 64, 7039-7048. [CrossRef]

97. Ronanki, D.; Williamson, S.S. Modular multilevel converters for transportation electrification: Challenges and opportunities. IEEE Trans. Transport. Electrific. 2018, 4, 399-407. [CrossRef]

98. Hao, H.; Covic, G.A.; Boys, J.T. A parallel topology for inductive power transfer power supplies. IEEE Trans. Power Electron. 2014, 29, 1140-1151. [CrossRef]

99. Ronanki, D.; Kelkar, A.; Williamson, S.S. Extreme fast charging technology—Prospects to enhance sustainable electric transportation. Energies 2019, 12, 3721. [CrossRef]

100. Jain, P.; Jain, T. Impacts of G2V and V2G power on electricity demand profile. In Proceedings of the 2014 IEEE International Electric Vehicle Conference (IEVC), Florence, Italy, 17-19 December 2014; pp. 1-8. [CrossRef]

(C) 2020 by the authors. Licensee MDPI, Basel, Switzerland. This article is an open access article distributed under the terms and conditions of the Creative Commons Attribution (CC BY) license (http://creativecommons.org/licenses/by/4.0/). 